\title{
Comparison of mesozooplankton communities at three shallow seamounts in the South West Indian Ocean
}

Noyon Margaux ${ }^{1,{ }^{*}}$, Rasoloarijao Zo ${ }^{1}$, Huggett Jenny ${ }^{3,4}$, Ternon Jean-Francois ${ }^{5}$, Roberts Michael ${ }^{1,2}$

1 UK-SA NRF/DST Bilateral Research Chair: Ocean Sciences \& Marine Food Security, Nelson Mandela University, Port Elizabeth, South Africa

2 National Oceanography Centre, Southampton, United Kingdom

3 Oceans and Coastal Research, Department of Environmental Affairs, Private Bag X4390, Cape Town, 8000 , South Africa

${ }^{4}$ Marine Research Institute, Department of Biological Sciences, University of Cape Town, Private Bag

X3, Rondebosch, 7701, Cape Town, South Africa

${ }^{5}$ MARBEC, Univ. Montpellier, CNRS, Ifremer, IRD, Sète, France

* Corresponding author : Margaux Noyon, email address : margauxnoyon@gmail.com

\begin{abstract}
:
Seamounts are recognised as hotspots of biodiversity, attracting large numbers of top predators, but the underlying mechanisms are still unclear. We studied mesozooplankton abundance and size distribution at three shallow seamounts $(60 \mathrm{~m}, 240 \mathrm{~m}$ and $18 \mathrm{~m}$ deep) in the South West Indian Ocean, along a latitudinal gradient $\left(19^{\circ} \mathrm{S}, 27^{\circ} \mathrm{S}\right.$ and $\left.33^{\circ} \mathrm{S}\right)$. Samples were analysed using a ZooScan, allowing the use of a size-based approach. Differences were observed between seamount areas, but overall zooplankton communities did not seem to be affected by the changes in topography. Only in the lee of La Pérouse seamount was the zooplankton community slightly more concentrated than upstream, suggesting that zooplankton were flushed downstream of the seamount. The southernmost and shallowest seamount, Walters Shoal, had low abundance and its size spectrum differed greatly from the two other seamounts further north. These differences were attributed to seasonality and mesozooplankton population dynamics, whereas the other two seamounts exhibited a more "typical" oligotrophic pelagic ecosystem, at equilibrium and dominated by small organisms. At the time of sampling, the unnamed seamount south of Madagascar was influenced by a mesoscale dipole that impacted the zooplankton distribution, potentially masking any seamount effect. The normalised biomass spectrum approach contributed to a better understanding of the ecosystem dynamics (i.e. equilibrium vs. non-steady state) but revealed little variability within a stable oligotrophic environment.
\end{abstract}

Keywords : Normalised Biovolume Size Spectrum (NBSS), mesoscale eddies, topography, oligotrophic environment, pelagic ecology 
39 Seamounts have been identified as "hotspots" of biodiversity and productivity, inhabited by

40 large fish aggregations (e.g. Genin, 2004; Morato et al., 2010a; Rogers, 2018, 1994). In recent years, they have been increasingly studied by oceanographers to understand their functioning, as well as by conservation entities attempting to preserve a pristine ecosystem and avoid overexploitation (e.g. Campos et al., 2019; Morato et al., 2010b; Warner, 2018). The underlying mechanisms that explain these aggregations of top predators are nonetheless far from being understood and many hypotheses have been put forward (Genin, 2004; Pitcher and Bulman, 2007). As described by Bakun (2006), three mechanisms must co-occur to allow an increase in biomass within a certain location: retention, enrichment, and concentration; and seamounts have the potential to satisfy all three criteria. Retention mechanisms that entrap a body of water on top of seamounts, such as Taylor columns, have been observed in very specific environments depending on currents,

51 the size and the location of the seamount (Chapman and Haidvogel, 1992; White et al., 52 2007). Enrichment associated with seamounts has rarely been observed (reviewed by 53 Rogers, 2018) but is often attributed to localised upwelling, induced by the topography and 54 uplift of nutrients into the euphotic layer (Lemos et al., 2018; Mendonça et al., 2012). 55 Advection, together with entrapment, will also result in increased production, and will be even more pronounced if the advected water mass is already enriched due the proximity of 57 a continental shelf or another seamount.

58 In situ measurements have shown that zooplankton biomass is, in many cases, either not 59 affected, or sometimes lower above the summit compared to the surrounding waters, 60 especially over shallow seamounts that penetrate the euphotic zone (Carmo et al., 2013; 61 Denda and Christiansen, 2014; Dower and Mackas, 1996; Genin et al., 1994; Haury et al., 
2000; Martin and Christiansen, 2009). The main reason put forward is the increase in predation pressure by bentho-pelagic or pelagic predators associated with seamounts (e.g. Frederick et al., 2018; Haury et al., 2000, 1995; Hosegood et al., 2019; Martin and Christiansen, 2009). Shallow topography (including continental shelves) concentrates zooplankton as the same number of organisms are contained within a shallower depth. Zooplankton that undergo diel vertical migration (DVM) can be trapped on the summit during their daily descent, known as topography blockage (Genin, 2004; Martin and Christiansen, 2009). This rise in zooplankton concentration, together with an intensifying flow on top of seamounts, increases prey encounter rates. Some pelagic predators would thus simply need to maintain their position above the seamount to benefit from an enhanced prey abundance passing through, therefore called the "feed rest" hypothesis (Genin, 2004). The impact of this predation can also be detected downstream of the seamount, with the formation of "gaps" in the zooplankton distribution (Dower and Mackas, 1996; Genin et al., 1994; Haury et al., 2000). Some authors have also suggested that zooplankton are 'washed' downstream of the seamount due to stronger currents above the seamount and are thus found in higher concentrations downstream compared to upstream of the seamount (Dower and Mackas, 1996; Genin, 2004). The last and more speculative hypothesis is related to the capacity of zooplankton, especially larger organisms, to horizontally avoid abrupt topography (Martin and Christiansen, 2009; Rogers, 1994). The mechanisms causing this behaviour are, however, not yet known.

Besides influencing zooplankton biomass, seamounts can also change the composition of the zooplankton community in their vicinity (Frederick et al., 2018; Martin and Christiansen, 2009). Inter- and intra-species interactions, as well as allochthonous growth, may alter the trophic structure of the advected zooplankton community. Amongst the approaches to investigate changes in zooplankton communities, size spectra have been widely used over the past two decades (reviewed by Sprules and Barth, 2015), partially related to the increase in technologies allowing semi-automated measurement and identification of plankton. Size structure is considered a useful metric for monitoring changes in plankton community structure and energy flux within a system (e. g. Basedow et al., 2010; Dai et al., 2016; García-Comas et al., 2014; Giering et al., 2018; Quinones et al., 2003; San Martin et al., 2006; Zhou et al., 2004). Size spectrum theory is based on predator-prey relationships and predicts a negative linear fit between biomass and size on a log-log scale (Platt and 
Denman, 1977; Silvert and Platt, 1978). The most common metric used is the normalised biomass size spectrum. The parameters extracted from the normalised biomass size spectrum are inherent properties of the zooplankton community. One of these parameters, the slope, provides an index of the size distribution of the plankton and should be close to -1 in a system that includes several trophic levels (Brown et al., 2004). A steeper slope indicates a higher proportion of small to large organisms, which could indicate an increase in reproduction and thus productivity (Zhou, 2006). The linear fit of the normalised biomass size spectrum is related to the stability of the ecosystem meaning that a deviation from linearity (i.e. low linear fit) can imply pulses of energy passing through the system and thus a non-steady state (e. g. Quinones et al., 2003; Rodriguez and Mullin, 1986).

It is generally assumed that season, the shape and depth of a seamount as well as the mesoscale current dynamics around it are important factors influencing the ecosystem associated with the seamount (Rogers, 2018, 1994). In this study, we selected three seamounts characterised by different topography and mesoscale conditions, and located along a latitudinal gradient in the South West Indian Ocean (SWIO). We used zooplankton abundance, biovolume and biovolume size spectrum parameters to investigate differences in the zooplankton communities at these three seamount ecosystems, and to explore whether topography had a discernible effect on zooplankton, stronger than the other drivers affecting the waters surrounding the seamounts.

\section{Methods}

\subsection{Study areas}

The three studied seamounts, La Pérouse, an unnamed seamount on the Madagascar Ridge - named MAD-Ridge hereafter, and Walters Shoals, are located along a latitudinal gradient in the SWIO at $19.43^{\circ} \mathrm{S}, 27.29^{\circ} \mathrm{S}$ and $33.12^{\circ} \mathrm{S}$, respectively (Fig. 1). La Pérouse is $60 \mathrm{~m}$ deep surrounded by depths of about $3000 \mathrm{~m}$, with a very uneven contour and steep slopes. It is in the path of the westward-flowing South Equatorial Current (SEC) and subject to limited mesoscale activity (Annasawmy et al., this issue). The two other seamounts are located on the Madagascar Ridge which has a bottom depth varying between approximately 1000 and $2500 \mathrm{~m}$. MAD-Ridge is located about $225 \mathrm{~km}$ south of the southern tip of Madagascar with its summit at $240 \mathrm{~m}$ depth. This seamount is influenced by the South-East Madagascar 
Current (SEMC) and by strong mesoscale activity with many eddies formed all year round (de Ruijter et al., 2004a; Halo et al., 2014). Walters Shoal has a caldera-like shape with shallow circular walls, reaching $18 \mathrm{~m}$ depth at its sides, with a deeper centre at about $50 \mathrm{~m}$. It is located near the Southern Indian Subtropical Gyre, and mesoscale turbulence in the vicinity is very low (Pollard and Read, 2017). All three seamounts have been identified as foraging areas for birds and other predators (Roberts et al., this issue).

\subsection{Sampling}

Mesozooplankton samples were collected at 46 stations during three cruises: La Pérouse (DOI: 10.17600/16004500) from 21-27 September 2016, MAD-Ridge (DOI: 10.17600/16004800) from 14-22 November 2016, both on the $R / V$ Antea, and Walters Shoal (DOI: 10.17600/17002700) from 30 April to 7 May 2017 on the $R / V$ Marion Dufresne (Table 1 sup. material). Ten stations were sampled at La Pérouse, 23 at MAD-Ridge and 13 at Walters Shoals. For La Pérouse and MAD-Ridge, stations were classified as either "on" or "off" the seamount based on the topography. The "on" stations were located above the summit and over the slopes of the seamount ( 6 at La Pérouse and 6 at MAD-Ridge) while the bottom depth of the "off" seamount stations was similar to the seafloor in the greater vicinity of the seamount ( $n=4$ and 15 stations at La Pérouse and MAD-Ridge, respectively). The stations "off" the seamount were generally more than $15 \mathrm{~km}$ away from the seamount, except for station 2 at La Pérouse which was only $7 \mathrm{~km}$ away from the seamount. At MADRidge, an extra 3 stations were sampled on the northern side of the south-north transect and which were classified as "shelf" stations being influenced by the Madagascan shelf productive waters (Fig. 2). These stations were sampled to have a zooplankton "shelf" signature to compare with the offshore stations as cross-shelf transport exists in this region and can influence zooplankton composition within eddies (Noyon et al, 2018). At Walters Shoal, due to the draught of the ship ( $7 \mathrm{~m})$, no samples were taken on top of (or inside) the seamount, and due to ship time constraints, no "off" seamount stations were sampled. Only stations on the slopes were sampled, all around the seamount $(n=13)$. and Walters Shoals, and using a Hydrobios Midi Multinet $\left(0.25 \mathrm{~m}^{2}\right.$ mouth area) at MAD- 
shallower when the bottom depth was less than $200 \mathrm{~m}$ (i.e. on the seamount). All the nets were fitted with $200 \mu \mathrm{m}$-sized mesh and a flowmeter. Zooplankton samples were preserved in buffered formaldehyde ( $4 \%$ final concentration). Sampling was conducted during day time only. One zooplankton sample was collected at each station, and for MAD-Ridge the five nets of the Multinet were analysed individually.

At each station, a seabird 911+ CTD-F (conductivity, temperature, depth - fluorescence) was deployed to measure environmental parameters of the water column down to $1000 \mathrm{~m}$ depth, or to the bottom when shallower. The fluorescence sensors were calibrated using discrete in situ chlorophyll $a(\mathrm{Chl} a)$ concentrations, measured by High Performance Liquid Chromatography (HPLC) and collected at various depths on all three cruises. Integrated Chl $a$ concentration $\left(\mathrm{mg} \mathrm{m}^{-2}\right.$ ) was calculated for the upper $200 \mathrm{~m}$ of the water column or the whole water column when the bottom depth was shallower than $200 \mathrm{~m}$. The mixed layer depth (MLD) was determined as the depth at which the density increases by $0.08 \mathrm{~kg} \mathrm{~m}^{-3}$ from a depth of $10 \mathrm{~m}$. The depth of the nutricline was defined as the depth where the concentrations of nitrate and nitrite reach $1 \mu \mathrm{g} \mathrm{Kg}^{-1}$ (Dufois et al., 2014). As the nutrients were measured using discrete samples, the concentration between two depths was extrapolated using a linear regression.

Fortnightly averages and standard deviations of sea surface temperature (SST, in ${ }^{\circ} \mathrm{C}$ ) and surface $\mathrm{Chl} a$ concentration $\left(\mathrm{mg} \mathrm{m}^{-3}\right.$ ) were calculated using MODIS-Aqua products from 2003 to 2018 (for more details see Demarcq et al., this issue) over each seamount area (red boxes in Fig. 1).

\subsection{Zooplankton sample analysis}

The zooplankton samples were analysed using a Hydroptic ZooScan as described in Gorsky et al. (2010). Briefly, an aliquot of each sample of 1000 to 15000 particles was poured into the scanning tray. The raw images were processed and divided into thumbnails using ZooProcess and subsequently images containing more than one organism were separated digitally and reprocessed (Vandromme et al., 2012). All thumbnails were uploaded and classified on the Ecotaxa website (Picheral et al., 2017), using a pre-existing learning set and the random forest method. The pre-sorted thumbnails were then manually validated and moved into their correct category when prediction failed. The volume of each particle $\left(\mathrm{mm}^{3}\right)$ was calculated based on an ellipsoidal shape, using the major and minor axes. Particle size 
was expressed as equivalent spherical diameter (ESD in $\mathrm{mm}$ ). Each count and volume measured was then calculated for the whole sample and divided by the amount of seawater filtered by the net to provide abundance (ind $\left.\mathrm{m}^{-3}\right)$ and biovolume $\left(\mathrm{mm} \mathrm{m}^{-3}\right)$.

We grouped the taxa into 13 groups as shown in Tables 3 and 4 . The category "gelatinous zooplankton" regroups all hydrozoa, siphonophora and thalicea. "Harosa" corresponds to the broad category of protists (e.g. radiolaria, phaeodaria, foraminifera, spumellaria). Parts of organisms, images of multiple organisms as well as unidentified organisms were removed from the counts presented here.

The size spectra were computed using 14 size bins of logarithmically increasing biovolume interval, from $0.18 \mathrm{~mm}$ ESD $~ 0.0031 \mathrm{~mm}^{3}$ to $6.50 \mathrm{~mm}$ ESD $144.31 \mathrm{~mm}^{3}$. The biovolume and Normalised Biovolume Size Spectra (NBSS) were computed by plotting the biovolume and the $\log 10$ of normalised biovolume, respectively, on the $\mathrm{Y}$-axis, against the log10 of the volume of each size bin (Platt and Denman, 1977; Zhou and Huntley, 1997). The normalised biovolume (in $\mathrm{m}^{-3}$ ) was obtained by dividing the total biovolume in each size bin by the volume of that bin interval $\Delta \mathrm{V}$ (in $\mathrm{mm}^{3}$ ). A linear regression was fitted to the NBSS using the least squares method. To take into account the bias of not properly sampling the small organisms, which are not always retained by a $200 \mu \mathrm{m}$-mesh nets, the smallest size bin used for the linear regression was the mode of the NBSS (García-Comas et al., 2014). In this case, the $4^{\text {th }}$ size bin was used as the lowest limit of the linear fit $\left(0.369 \mathrm{~mm}\right.$ ESD $\left.0.0263 \mathrm{~mm}^{3}\right)$. From this linear regression, the slope, the intercept and the linear fit $\left(R^{2}\right)$ are used in this study.

We also calculated a size diversity index $\left(\mathrm{H}^{\prime}\right)$, based on the Shannon diversity index and using a kernel distribution to estimate the frequency parameter $p_{i}$ (Quintana et al., 2008):

$$
H^{\prime}=\sum_{i}^{s} p_{i} \log p_{i}
$$

Because sometimes NBSS diverts from the theoretical linear model, this index takes into account irregularities in the size distribution, such as "domes" and "dips" that sometimes occur in NBSS. In theory, the flatter the slope is, the higher the size diversity index should be. 
The zooplankton parameters that were tested throughout this study were total abundance and total biovolume, abundance and biovolume of specific taxa, slope, intercept and linear

218 fit $\left(r^{2}\right)$ of the NBSS as well as the size diversity index $\left(H^{\prime}\right)$. At MAD-Ridge, each net sample (5 per station) were analysed individually with the ZooScan. To enable comparison between the 3 cruises, we combined the 5 nets at each station only in the calculation a posteriori. For this, the number of organisms in each net was summed together and divided by the sum of the water filtered by all 5 nets, which would be the equivalent to towing a single net.

The data were not normally distributed. Hence Kruskal-Wallis tests (KW) were performed to investigate if total zooplankton abundance and biovolume, and size diversity changed between cruises and "on/off" the seamount. Spearman's coefficients $\left(r_{s}\right)$ were used to investigate correlations between variables. All stations were considered for the comparison between cruises but only La Pérouse and MAD-Ridge were used to test the possible effect of the seamount. Analyses of covariance (ANCOVA) were used to compare the slopes and the intercepts of the NBSS to highlight differences between cruises and stations as well as between on and off seamount. For a synoptic view of the results, a non-metric multidimensional scaling (nMDS) ordination was performed on the NBSS parameters described above (i.e. slope, linear fit, size diversity, intercept) and the biovolumes of the 14 size bins used in the NBSS, using all the stations of the three cruises. The "envfit" function from R (Vegan package) was used to plot the environmental parameters on the ordination plot. Depth of the nutricline was found to be correlated both with the temperature at $100 \mathrm{~m}$ $\left(r_{s}=0.88\right)$ and the Deep Chl $a$ Maximum (DCM) depth $\left(r_{s}=0.94\right)$. Amongst these three variables, the DCM depth was the least correlated with SST $\left(r_{s}=0.6\right)$ and was therefore selected for the analyses. The other environmental parameters used were integrated $\mathrm{Chl} a$ concentration, MLD, SST and Chl $a$ concentration at the DCM. All the data analyses were performed using R (R Core Team, 2018).

\section{Results}

\subsection{Environmental conditions at the three seamounts}

The hydrographic conditions at La Pérouse and MAD-Ridge were more similar to each other, compared to Walters Shoal (Table 1). At the time of sampling, SSTs were 3 to $4{ }^{\circ} \mathrm{C}$ warmer at 
La Pérouse and MAD-Ridge with $23.6^{\circ} \mathrm{C}$ and $24.5^{\circ} \mathrm{C}$ respectively, compared to $20.5^{\circ} \mathrm{C}$ at

Walters Shoal. The two northern seamounts had deep DCMs and nutriclines of more than $100 \mathrm{~m}$ while the Walters Shoal's DCM was only $37 \mathrm{~m}$ and the nutricline was at about $53 \mathrm{~m}$ for the stations sampled around the seamount. The integrated $\mathrm{Chl} a$ and the $\mathrm{Chl} a$ concentration at the DCM were in the same range at all three seamounts. Walters Shoal's integrated Chl $a$ was only slightly higher by $\sim 3 \mathrm{mg} \mathrm{m}^{-3}\left(23 \mathrm{mg} \mathrm{m}^{-3}\right)$ compared to the other two seamounts $\left(\sim 20 \mathrm{mg} \mathrm{m}^{-3}\right)$.

The main surface current at La Pérouse was orientated north-westwards for the first part of the cruise but changed to southwards after 26 September shortly before the last two stations, 23 and 24, were sampled. Stations 3 and 6 were therefore in the lee of the seamount at the time of sampling (see Marsac et al., this issue, for more details). At MADRidge, a dipole was present during sampling (Fig. 2), and the west-east transect crossed both the cyclonic and anticyclonic eddies. Station 2 was located in the cyclonic eddy while stations 8 to 12 were in the anticyclonic eddy (altimetry and in situ measurements used to classify these stations are presented in Annasawmy et al., this issue). The stations located along the south-north transect were mostly in the anticyclonic eddy (stations 16 to 25). The other stations may have been influenced by the eddies but did not fulfil all the physical criteria to qualify as part of either the cyclone or anticyclone and were therefore named "transition". These stations were located either between the two eddies (station 6) or on the outside edges of the anticyclone (stations 14, 15 and 26 to 28). Stations 29 to 31, the closest to the Madagascan shelf were classified as "shelf", as described earlier, due to the filament of high $\mathrm{Chl}$ a concentration flowing from the South-East tip of the Madagascar shelf. At Walters Shoal, surface currents were not strong and highly variable, changing sporadically during the cruise (Demarcq et al., this issue).

The three seamounts are located at different latitudes. Bi-monthly averages of SST followed this latitudinal gradient from the warmer La Pérouse in the North, to the cooler Walters Shoal in the South, with temperatures varying by 4 to almost $6^{\circ} \mathrm{C}$ depending on the month (Fig. 3). The climatology of surface $\mathrm{Chl} a$ concentration shows that La Pérouse had the lowest surface $\mathrm{Chl}$ a concentration of the three seamounts all year round, while Walters Shoal had a higher $\mathrm{Chl} a$ concentration than MAD-Ridge during austral winter and spring 
Pérouse and then MAD-Ridge, as highlighted by the coefficient of variation for surface $\mathrm{Chl} a$ concentration (Fig. 1). Sampling at these three locations occurred during different months of the year. The climatologies of SST and $\mathrm{Chl} a$ indicate that La Pérouse and MAD-Ridge were sampled towards the end of the productive season while Walters Shoal was sampled at the beginning (Fig. 3). Despite this difference, the levels of SST and Chl $a$ from remote sensing, at the time of the cruises, are similar at all three seamounts, agreeing with the in situ observations described above.

\subsection{Comparison of the three seamount zooplankton communities}

\subsubsection{Total abundance and biovolume}

Total zooplankton abundance varied between the seamounts with significantly higher

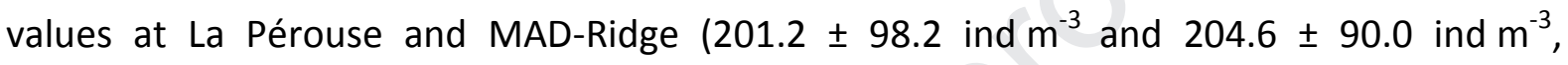
respectively) compared to Walters Shoal $\left(60.8 \pm 53.4\right.$ ind $\mathrm{m}^{-3}$, KW test $p<0.001$, Table 2$)$. Similarly, the averaged total biovolume at La Pérouse $\left(42.81 \pm 15.14 \mathrm{~mm}^{3} \mathrm{~m}^{-3}\right)$ and MADRidge $\left(45.64 \pm 20.92 \mathrm{~mm}^{3} \mathrm{~m}^{-3}\right)$ were significantly higher than at Walters Shoal $(12.69 \pm 8.27$ $\mathrm{mm}^{3} \mathrm{~m}^{-3}, \mathrm{KW}$ test $\left.p<0.001\right)$.

\subsubsection{Size Spectrum and diversity}

The NBSS also differed between the three seamounts with the steepest slope at MAD-Ridge, followed by La Pérouse and Walters Shoal (Table 2 and Fig. 4). It is worth noting that the difference between La Pérouse and MAD-Ridge was only due to station 23 at La Pérouse, which had a very flat slope of -0.57 . Once this station was removed, the NBSS slopes at La Pérouse and MAD-Ridge were similar, being $-0.95 \pm 0.10$ and $-1.00 \pm 0.09$, respectively (ANCOVA, $p=0.094$ ). Walters Shoal had a flatter slope of $-0.79 \pm 0.09$ compared to the other two seamounts. The NBSS intercepts were higher at La Pérouse and MAD-Ridge compared to Walters Shoal, with averages of $0.59,0.50$ and -0.20 , respectively. Over the whole size range, Walters Shoal biovolumes were lower than at the other two seamounts (Fig. 5a). The NBSS linear fit $\left(R^{2}\right)$ was high at La Pérouse and MAD-Ridge (0.93 and 0.94, respectively) while it dropped to 0.78 at Walters Shoal. The size diversity indices were significantly different at each seamount with averaged values of, in decreasing order, 2.34 at MAD-Ridge, 2.27 at La Pérouse and 2.18 at Walters Shoal (KW test, $p<0.001$ ).

\subsubsection{Zooplankton taxonomic composition}


Overall, copepods comprised about $70 \%$ of the total zooplankton abundance with Calanoida being the most abundant group and Oithonidae second (Table 3). Appendicularia and Chaetognatha were the next most abundant taxa.

Calanoida and Chaetognatha together represented around $50 \%$ of the total zooplankton biovolume at all three seamounts but their proportions varied between seamounts (Table 4). Total biovolume at La Pérouse and MAD-Ridge comprised about 30\% Calanoida and 20\% Chaetognatha while at Walters Shoals only $13 \%$ was comprised by Calanoida with $40 \%$ being Chaetognatha. This was largely due to the low biovolume overall of Calanoida at Walters Shoal (only $\sim 2 \mathrm{~mm}^{3} \mathrm{~m}^{-3}$ ) compared to the other two seamounts ( $15 \mathrm{~mm}^{3} \mathrm{~m}^{-3}$ ). Low biovolume here was clearly visible for Calanoida, especially for size bins of $0.6 \mathrm{~mm}$ ESD ( $0.110 \mathrm{~mm}^{3}$ ) and larger, and for chaetognatha (Figs. $5 \mathrm{~b}$ and c) but was also evident for amphipoda, appendicularia, other copepoda and other crustacea (data not shown).

\subsection{La Pérouse}

There were no significant differences between the stations on and off the La Pérouse seamount for any of the zooplankton related parameters measured (i.e. total abundance and biovolume, NBSS parameters, size diversity, KW test, $p>0.05)$. Zooplankton abundance and biovolume varied between stations, but no major differences in size composition were observed between on and off seamount stations (Figs. 6 and 7).

On the seamount, the two stations downstream (west) of the seamount had the highest abundance and biovolume, with 424 ind $\mathrm{m}^{-3}$ and $66 \mathrm{~mm}^{3} \mathrm{~m}^{-3}$ at station 6 , and 231 ind $\mathrm{m}^{-3}$ and $65 \mathrm{~mm}^{3} \mathrm{~m}^{-3}$ at station 3. On the upstream side of the seamount, stations 4 and 9 had low abundance (184 and 145 ind $\mathrm{m}^{-3}$ respectively). The biovolume at station 4 was low compared to the other stations $\left(29 \mathrm{~mm}^{3} \mathrm{~m}^{-3}\right)$ while station 9 biovolume was almost as high as at station 6 and $3\left(53 \mathrm{~mm}^{3} \mathrm{~m}^{-3}\right)$. However, this was mainly due to one trachymedusa scanned, which was larger than $4 \mathrm{~mm}$, and so should perhaps be considered a methodological bias (Fig. 7). Stations 23 and 24 are described separately from the other stations as they were sampled at the end of the cruise, after the main surface current had changed direction. Station 23 had a very low abundance but a high biovolume $\left(85\right.$ ind $\mathrm{m}^{-3}$ and $41 \mathrm{~mm}^{3} \mathrm{~m}^{-3}$ ) while station 24 had both a low abundance and biovolume (130 ind $\mathrm{m}^{-3}$ and $17 \mathrm{~mm}^{3} \mathrm{~m}^{-3}$ ). The total abundance of zooplankton off the La Pérouse seamount (stations 1, 2, 8 and 10) was relatively similar with an average of 170 ind $\mathrm{m}^{-3}$ except for 
station 10 which had 302 ind $\mathrm{m}^{-3}$. The biovolume was similar at all four stations with an average of $39 \mathrm{~mm}^{3} \mathrm{~m}^{-3}$.

Abundance and biovolume were not correlated at La Pérouse $\left(r_{s}=0.36\right.$, Table 5). Each station sampled at La Pérouse differ significantly from each other in their NBSS slope and intercept (ANCOVA, $p<0.001, \mathrm{n}=10$ ). Station 23 had the flattest slope $(-0.57)$ due to the quasi absence of smaller organisms between 0.3 and $0.5 \mathrm{~mm}$ ESD, mostly Calanoida, Oithona and Oncaea (Fig. 5d, e, $f$ and 7) but a high biovolume of larger Calanoida $~ 0.5$ to $1.2 \mathrm{~mm}$ ESD, with station 6 exhibiting the highest total zooplankton abundance at La Pérouse (Fig. 5e). The highest size diversity index at La Pérouse was also found at station 23 (2.370) indicating a more even distribution of zooplankton sizes across the spectrum sampled compared to the other stations. Station 3 differed significantly from the others with a slope of -0.74 and an intercept of 0.87 . This station had biovolumes of Calanoida in all size bins which were similar to the other stations, but had a higher proportion of Chaetognaths, euphausiids and amphipods larger than $0.5 \mathrm{~mm} \mathrm{ESD}$, especially between 1.2 and $2.5 \mathrm{~mm}$ ESD (Figs $5 \mathrm{~d}, \mathrm{e}, \mathrm{f}$ and 7 ). The slopes and intercepts of the other stations did not differ significantly from each other $(n=8$, ANCOVA, $p<0.001)$. The slope of these 8 stations combined was -0.94 with an intercept of 0.56 . Station 6 , which had the highest abundance and biovolume of zooplankton at La Pérouse, had one of the highest NBSS intercepts $(0.82)$ and the steepest slope, owing to the high biovolume of small Calanoida of $\sim 0.3-1.2 \mathrm{~mm}$ ESD (Fig. 5e). The linear fit coefficient was stable throughout the stations at La Pérouse being 0.99 except for stations 1 and 2 where it was slightly lower (-0.96 and -0.98 respectively). Overall, the biovolume at La Pérouse was correlated with the NBSS intercept $\left(r_{s}=0.89\right)$, and the size diversity index was correlated with the slope $\left(r_{s}=0.79\right.$, Table 5$)$.

The integrated $\mathrm{Chl}$ a concentration was variable amongst the La Pérouse stations, but the lowest values were found at stations 3 and 6 with 14.3 and $16.9 \mathrm{mg} \mathrm{m}^{-2}$ respectively, which also had the highest zooplankton biovolumes. The other 4 stations on the seamount had an average of $23.6 \mathrm{mg} \mathrm{m}^{-2}$. Integrated $\mathrm{Chl} a$ was indeed negatively correlated with total abundance $\left(r_{s}=-0.72\right)$, biovolume $\left(r_{s}=-0.68\right)$ and the intercept $\left(r_{s}=-0.68\right)$ at La Pérouse. The vertical distribution of the Chl $a$ varied, with a relatively shallow DCM at $85 \mathrm{~m}$ for stations 6 and 23, and a DCM of $65 \mathrm{~m}$ at station 9 . The other stations off the seamount had DCMs deeper than $100 \mathrm{~m}$. The deeper the DCM was at La Pérouse, the steeper the slope of 
the NBSS was $\left(r_{s}=-0.72\right)$. The temperature and $\mathrm{Chl} a$ profiles at the four stations off the seamount were very similar. They all had deep DCMs at about $100 \mathrm{~m}$ or deeper, and the integrated $\mathrm{Chl} a$ concentration averaged $19.1 \mathrm{mg} \mathrm{m}^{-2}$.

\subsection{MAD-Ridge}

At MAD-Ridge, the stations on the seamount (slopes and summit) had a mean zooplankton abundance of $157 \pm 26$ ind $\mathrm{m}^{-3}(\mathrm{n}=6)$ and a mean biovolume of $32.8 \pm 4.9 \mathrm{~mm}^{3} \mathrm{~m}^{-3}$ but were not significantly different from the stations off the seamount $\left(199 \pm 77\right.$ ind $\mathrm{m}^{-3}$ and $45.7 \pm$ $22.1 \mathrm{~mm}^{3} \mathrm{~m}^{-3}$, respectively, KW test $\left.\mathrm{p}>0.05\right)$.

On the East-West transect, stations 2, 6, 14 and 15, located in the cyclonic eddy and the edges of the anticyclone (transition zone), showed high integrated abundance and biovolume (240 ind $\mathrm{m}^{-3}$ and $49.9 \mathrm{~mm}^{3} \mathrm{~m}^{-3}$, Figs 7 and 8 ). Stations $8,9,10$ and 12 , classified as anticyclone, were similar with low abundance and biovolume, except for station 12 which had a greater biovolume due to the size class $>4 \mathrm{~mm}$ containing a few large individuals (15.8 $\mathrm{mm} \mathrm{m}^{-3}, 0.18$ ind $\mathrm{m}^{-3}$ ). On the North-South transect, station 18 , south of the seamount, had a greater abundance and biovolume compared to the other stations sampled in the anticyclone. Considering all the stations within the anticyclone, with the exception of station 18 , the average total abundance was $147 \pm 21$ ind $\mathrm{m}^{-3}$ and the biovolume $33.3 \pm 6.1 \mathrm{~mm}^{3} \mathrm{~m}^{-3}$ ( $n=12$ ), both relatively low compared to the other stations sampled at MAD-Ridge. Out of the three stations classified as shelf, only stations 29 and 30 had a high abundance of about 400 ind $\mathrm{m}^{-3}$ and a high biovolume of $75 \mathrm{~mm}^{3} \mathrm{~m}^{-3}$. Station 31 had average abundance and biovolume, similar to the other stations.

The zooplankton was concentrated in the upper $100 \mathrm{~m}$ with very low abundance between 100 and $200 \mathrm{~m}$, and the highest densities were often found in the upper 30 to $50 \mathrm{~m}$ of the water column (Fig. 9). It seems that on the West-East transect, from stations 6 to 15, the highest concentrations were restricted to the upper net. Stations 2 and 18 had the highest concentrations that extended all the way down to about $100 \mathrm{~m}$, while the high concentrations at the two stations closer to the shelf, 29 and 30, were restricted to the upper $50 \mathrm{~m}$. The layer from 50 to $75 \mathrm{~m}$ depth at station 21 showed a small but intense patch of all the taxa. Multivariate analysis was performed on the taxonomic composition of each net at MAD-Ridge (not shown) and only the deepest nets grouped together. We can see however that, unlike the small Calanoida $(<1 \mathrm{~mm}$ ESD), larger zooplankton such as 
Chaetognaths and other large organisms ( $>2.7 \mathrm{~mm}$ ESD) have a patchy distribution, not

401

402

403

404

405

406

407

408

409

410

411

412

413

414

415

416

417

418

419

420

421

422

423

424

425

426

427

428

429

430 always following the general patterns of total abundance and biovolume (Fig. 9). Hence the proportion of each taxon in terms of abundance and biovolume were not necessarily similar at all the MAD-Ridge stations within the upper $100 \mathrm{~m}$ of the water column, but also did not form any clusters.

The NBSS slopes at the MAD-Ridge stations were similar to each other except for station 30 which had a significantly steeper slope of -1.34 (Fig. 8, ANCOVA, $p<0.001$ ). This station had the highest abundance of Calanoida $\left(252\right.$ ind $\mathrm{m}^{-3}$ ) within the size range of $\sim 0.68$ to $1.76 \mathrm{~mm}$ ESD of all the stations sampled, with peaks at $\sim 0.4 \mathrm{~mm}$ and $1.3 \mathrm{~mm}$ (Fig. 5h). Station 29, which had a steep slope (-0.95), also had a high abundance of Calanoida (174 ind $\mathrm{m}^{-3}$ ) with only one peak at about $1.2 \mathrm{~mm}$ ESD. The biovolume of Calanoida at station 29 was higher than at station 30, however (Fig. 5h). Stations 29 and 30 had a higher proportion of Calanoida copepods (45 and $51 \%$ ) than all the other stations on this transect (avg. 35\%). Another difference between these two stations was the low biovolume of Chaetognaths at station 29 compared to 30 (Figs $5 i$ and 9). The flattest slope of MAD-Ridge was at station 28 $(-0.87)$ but it was not significantly different from the others. Stations 2 and 18, which had amongst the highest abundance and biovolume of zooplankton at MAD-Ridge, had steep slopes, -0.97 and -1.01 respectively, but these were not significantly different from the other stations with lower abundance and biovolume. Both stations had a high biovolume of Calanoida of $\sim 0.4$ to $2.4 \mathrm{~mm}$ ESD with a peak at $\sim 2.2 \mathrm{~mm} \mathrm{ESD}$, slightly larger than what was observed at stations 29 and 30 (Fig. 5h). The biovolume spectra of Calanoida and Chaetognatha at the other stations were very similar, as shown in Figs 5 k and $5 \mathrm{I}$.

The slopes varied irregularly with depth (i.e. within each net) with an overall average of $0.89 \pm 0.1$ ( $n=115$, Fig. 9). For instance, the flattest slope was found at station 28 between 25 and 50m depth (-0.6) while the steepest slopes were at station 14 at 50-70 m depth (1.18) and station 26 in the upper $30 \mathrm{~m}$ of the water column $(-1.16)$.

The intercept was positively correlated with both abundance $\left(r_{s}=0.83\right)$ and biovolume $\left(r_{s}=\right.$ 0.91) showing high values at stations 2 (0.81), 18 (0.89) and 29 (0.89). The size diversity index changed sporadically with depth and station and was not correlated with the slope at MAD-Ridge. The linear fit was weakly correlated with size diversity $\left(r_{s}=0.44\right)$ indicating that the stronger the linear fit is (i.e. the closest to -1), the lower the size diversity is. 
No relationships were found between Integrated $\mathrm{Chl} a$ or $\mathrm{Chl} a$ concentration profiles and the horizontal or vertical distribution of zooplankton or any of the NBSS parameters described above.

\subsection{Walters Shoal}

At Walters Shoal, stations 1 and 14 had a greater abundance compared to the other stations at this seamount, with 136.4 and 195.6 ind $\mathrm{m}^{-3}$, respectively (Figs 7 and 10). These values are in the same range as the lowest values found at La Pérouse and MAD-Ridge. No pattern was found between any of the zooplankton parameters measured and the bottom depth at Walters Shoals. The size fraction 0.3 to $0.5 \mathrm{~mm}$ was the most abundant at all stations. The biovolumes at stations 1 and 14 to the south-west, 3 and 6 to the south-east, and 8 to the north west were higher compared to the other stations at Walters Shoal, with an average of $21.74 \mathrm{~mm}^{3} \mathrm{~m}^{-3}$ compared to $7.03 \mathrm{~mm}^{3} \mathrm{~m}^{-3}$ for the other stations. Many of these stations showed a substantial amount of biovolume in the size classes larger than $4 \mathrm{~mm}$, which was also the case at MAD-Ridge, but not at La Pérouse where it was evident at only one station. Abundance and biovolume were correlated at Walters Shoals $\left(r_{s}=0.88\right.$, Table 5). The proportion of each taxon was similar amongst stations in terms of abundance only. The proportion of biovolume for each taxon showed greater variability between stations with more than $50 \%$ of the total biovolume comprised of euphausiids at stations 1,8 and 12 , and of chaetognaths at stations $3,5,7,10,13$ and 14 .

The NBSS slopes did not differ significantly between stations (ANCOVA, $p=0.67$ ). Stations 14 and 1 , which had the highest abundance, had slopes of -0.9 and -0.84 respectively, not different from the other stations. The size distribution of Calanoida at station 14 revealed greater biovolumes than at the other Walters Shoal stations with a peak at $0.4 \mathrm{~mm}$, but very little biovolume between 0.4 and $1 \mathrm{~mm}$ ESD, which is where high biovolumes were measured at the other two seamounts (Fig. 5n). The biovolume of Chaetognaths at this station was very high and amongst the highest for all three seamounts (Fig. 5o). Station 1 had a high abundance of Oithonidae and other copepods (48 ind $\mathrm{m}^{-3}$ ) as well as a high biovolume of euphausiids $\left(13.6 \mathrm{~mm}^{3} \mathrm{~m}^{-3}\right)$, two groups that are not shown in Figure 5 . The slopes were negatively correlated with abundance $\left(r_{s}=-0.64\right)$ and positively correlated with size diversity $\left(r_{s}=0.59\right)$ but there was no correlation between size diversity and linear fit. 
461

462

463

464

465

466

467

468

469

470

471

472

473

474

475

476

477

478

479

480

481

482

483

484

485

486

487

488

489

490

491

None of the environmental parameters tested showed any significant relationship with the zooplankton abundance, biovolume nor NBSS parameters.

\subsection{Overview of all three seamounts and relationship with environmental parameters}

The nMDS performed on the biovolume of each bin of the NBSS (14 bins) and the NBSS parameters clearly discriminates Walters Shoal from La Pérouse and MAD-Ridge (Fig. 11). The stations with high abundance or biovolume stand out on the left hand-side of the ordination, especially stations 2, 18 and 29 from MAD-Ridge associated with the bin sizes 0.68 to $1.76 \mathrm{~mm}$ ESD. Stations 3 and 6 from La Pérouse are closely related to these three stations too, but station 3 has more larger organisms (closer to bin 2.23) than station 6 (close to 0.53). Station 30 from MAD-Ridge and station 10 from La Pérouse had high total biovolume and are grouped together for having a greater biovolume in the small bins 0.33 and $0.42 \mathrm{~mm}$ ESD compared to the other stations. La Pérouse station 23 is separated from the other stations and its closest size bin is $2.23 \mathrm{~mm}$ ESD. This station had a low abundance, an intermediate biovolume and a flat slope compared to the other stations at La Pérouse. We can also distinguish that all the stations sampled inside the anticyclone at MAD-Ridge are very similar to each other, except for station 18 as described earlier. Most of the stations classified as "transition" at MAD-Ridge are grouped together $(6,14,15,27)$ with the exception of 26 and 28. Station 26 was closest to the anticyclone and its northern edge had a zooplankton size composition similar to that inside the anticyclone. Station 28 differs due to a greater biovolume in the bin $2.23 \mathrm{~mm}$ ESD. Amongst the Walters Shoals stations, the total biovolume increases from the stations at the bottom right corners $(5,7$ and 10$)$ towards stations 1 and 14. Stations 1 and 14 have a greater biovolume in bin $3.6 \mathrm{~mm}$ ESD compared to the other stations. All the other stations at Walters Shoal have a lower biovolume than at the other two seamounts. They are characterised by a flat slope (less negative), a low size diversity index and a low linear fit. These three parameters are close to each other on the nMDS plot despite relatively low correlation coefficients between them $\left(r_{s}(\right.$ diversity $\sim$ slope $)=-0.43 ; r_{s}($ diversity $\sim$ linear fit $)=-0.31 ; r_{s}($ slope $\sim$ linear fit $\left.)=0.43\right)$.

Out of the 5 environmental parameters used in the Envfit (SST, depth of the DCM, Chl a concentration at the DCM, MLD and integrated $\mathrm{Chl} a$ ), SST had the highest correlation with the ordination $\left(r^{2}=0.65, p=0.001\right)$, followed by depth of the DCM $\left(r^{2}=0.34, p=0.001\right)$ which were slightly correlated $\left(\mathrm{r}_{\mathrm{s}}=0.6\right)$. Integrated $\mathrm{Chl} a, \mathrm{MLD}$ and $\mathrm{Chl} a$ concentration at 
the DCM were not significant and are not represented on the ordination. Hence in this study, overall, high (warm) SST and deep DCM were associated with the steepest slopes and the highest total biovolumes.

\section{Discussion}

\subsection{Comparison of the three seamount ecosystems}

The three study sites are located at different latitudes in the oligotrophic SWIO. Despite having clear differences in temperature and Chl a climatologies, the Longhurst (2007) classification, based on oceanographic features and $\mathrm{Chl} a$ profiles, places La Pérouse and Walters Shoals in the same bioregion, the Indian South Subtropical Gyre Province (ISSG), while MAD-Ridge belongs to the Eastern Africa Coastal Province (EAFR). What particularly distinguishes MAD-Ridge from the other two seamounts is the high meso-scale activity in the region due to the East Madagascar Current producing eddies over the Madagascan Ridge (de Ruijter et al., 2004b; Halo et al., 2014; Quartly et al., 2006). This seamount is also in the proximity of the Madagascan continental shelf (160 km approximately) which can influence biological material contained within eddies (e.g. Muhling et al., 2007; Noyon et al., 2019; Sabarros et al., 2009; Strzelecki et al., 2007; Thompson et al., 2007). Furthermore, body size of ectotherms tends to increase with latitude, known as Bergmann's rule (1847), mostly driven by temperature, season length and food availability although the underlying mechanisms are not fully understood (Blackburn et al., 1999; Watt et al., 2010). Considering the above and the fact that temperature and $\mathrm{Chl} a$ are important drivers of zooplankton distribution (Hirst and Bunker, 2003), one might have expected the zooplankton communities to differ at the three seamounts. However, the zooplankton communities at La Pérouse and MAD-Ridge were similar to each other, whereas Walters Shoal, the southernmost seamount, had very low biovolumes and abundances. The abundance of zooplankton observed during this study were in the same range as those observed previously in the Indian Ocean although the concentration at Walters Shoal was amongst the lowest recorded (Huggett, 2014; Madhupratap, 1983; Noyon et al., 2019; Säwström et al., 2014).

Sea surface temperature was slightly cooler $\left(3\right.$ to $4^{\circ} \mathrm{C}$ ) and integrated $\mathrm{Chl} a$ slightly higher by 2 to $3 \mathrm{mg} \mathrm{m}^{-3}$ at Walters Shoals compared to the other two seamounts. Cooler temperature 
induces a decrease in metabolic rates of organisms while increased food availability (i.e. Chl a) enhances metabolic rates (e.g. Hirst and Bunker, 2003). Given the low abundance at Walter Shoals, it seems that the temperature effect may have outweighed the food availability effect, or alternatively the food quality was poorer although we did not asses this during this cruise. The NBSS slope at Walters Shoal was flatter than at the other two seamounts, mostly due to the very low biovolume of Calanoida in the size range of 0.6 to $1.9 \mathrm{~mm}$ ESD (equivalent to biovolume of -0.95 to $0.60 \log \mathrm{mm}^{3}$ ). The linear fit of the slope was also low, a sign of irregularities in the size spectra. Some studies have emphasised the importance of NBSS diverging from linearity, when the size spectra show "domes" or "dips" due to instabilities or propagation of energy pulses through the system (García-Comas et al., 2014; Quinones et al., 2003; Rodriguez and Mullin, 1986; Sourisseau and Carlotti, 2006; Zhou, 2006). Sampling at Walters Shoal may have occurred during one such event while La Pérouse and MAD-Ridge, which both had a high linear fit, were in a steady state at the time of sampling. The three seamounts were sampled at different times of the year: La Pérouse in September, Austral spring, MAD-Ridge in November, Austral summer and Walters Shoal in May, Austral fall. According to the climatology at each location, Walters Shoals was sampled at the start of the annual productive season while La Pérouse and MAD-Ridge were sampled closer to the end. The increased productivity in winter in oligotrophic environments is often induced by a decrease in heat (i.e. solar radiation) and an increase in wind which breaks the stratification and leads to an increase of nutrients in the euphotic zone. Hence, we hypothesise that the mismatch observed here between $\mathrm{Chl} a$ and zooplankton at Walters Shoal could be due to the phenology of events: primary production had increased, yielding an increased $\mathrm{Chl}$ a concentration, yet a delay of a week to a month is needed to see any accumulation of zooplankton biovolume. The biovolume in the first few bins of the size spectra (which are not used in the calculation of the slope) were similar at all three seamounts. This can either highlight the presence of small copepods that are abundant in oligotrophic systems and not food limited (Hirst and Bunker, 2003), or that some of these copepods were juvenile stages of larger Calanoida copepods, hence mirroring an increase in reproduction rates. These irregularities in the size spectrum must be interpreted with caution, however, as they may also be due to other factors including methodological bias such as net avoidance, or large swimmers entering and leaving the system sampled (Quinones et al., 2003; Sourisseau and Carlotti, 2006; Zhou, 2006). The 
lower abundance of Calanoida could also be due to increased predation pressure. Both amphipods and chaetognaths, strong copepod carnivores, were in the same proportions at all three seamounts (abundance $\sim 5 \%$ of the total), but there were relatively more large chaetognaths at the Walters Shoals stations with greatest total zooplankton total abundance.

Overall, slopes were flatter when size diversity decreased which is contrary to the theory that flatter slopes suggest a more even distribution of organisms throughout all size classes. The fact that Walters Shoal had the flattest slope and the lowest diversity index may support the fact that the size spectrum was skewed towards large organisms with only few small organisms which concurred with the low linear fit measured there.

At most stations at La Pérouse and MAD-Ridge, the NBSS slopes were similar and relatively steep, close to -1 , with a high linear fit. This is the same as what Sheldon et al (1972) observed and slightly less than a slope of -1.22 which has been associated with typical steady-state open-ocean communities (Platt and Denman, 1977). A steep slope concurs also with the fact that temperature influences metabolic activity, hence low latitude environments are usually associated with smaller organisms with faster metabolic rates (Brown et al., 2004; Gillooly et al., 2001; Huntley and Lopez, 1992). The high linear fit is consistent with oligotrophic ecosystems in a steady-state, with few perturbations or bursts of production, thus not creating any domes or dips in the size spectrum (e.g. Barber and Hiscock, 2006; Dai et al., 2016; García-Comas et al., 2014; Lebourges-Dhaussy et al., 2014). The strong similarity between La Pérouse and MAD-Ridge was not expected considering that these two seamounts belong to different bioregions, and that MAD-Ridge is influenced by meso-scale activity as well as being located close to the productive Madagascan shelf. However, the fact that none of these factors appeared to influence the average values at MAD-Ridge might be because out of a total of 23 stations, only one station was sampled inside the cyclonic eddy and three were influenced by the shelf. Some differences in zooplankton communities were observed for these specific stations, however, and are discussed later on.

Flat slopes are the consequence of a higher proportion of large organisms compared to small ones and this is often interpreted as an increase in energy available in food webs (e.g. Brown et al., 2004; García-Comas et al., 2014; Zhou, 2006). Nevertheless, an increase in 
nutrients will stimulate primary production which will lead to an increase in secondary production and therefore an increase in small zooplankton (i.e. juveniles), translating into a steeper NBSS slope (García-Comas et al., 2014; Giering et al., 2018; Zhou, 2006; Zhou and Huntley, 1997). Observations have shown that trophic transfer efficiency increases in food limited environments and that fast turn-over rates of small primary producers enables a higher biomass of predators to be supported (Calbet, 2001; García-Comas Carmen et al., 2016; Gasol et al., 1997; Irigoien et al., 2014; San Martin et al., 2006). Using the NBSS slope on its own seems too limited to provide an adequate understanding of the system and several NBSS parameters should be considered simultaneously to better understand the dynamics of a system at a particular moment. For instance, at Walters Shoal, the flat slopes interpreted together with the low linear fit and the size diversity probably reflect a low energy transfer towards higher trophic levels. This kind of conclusion should be taken with caution though as this study focused only on a limited size spectrum (200 $\mu \mathrm{m}$ to $\sim 4 \mathrm{~cm})$.

\subsection{Meso- and small-scale variability at each seamount and possible seamount effect}

\subsubsection{MAD-Ridge}

Zooplankton abundance and size structure at MAD-Ridge was influenced more by mesoscale variability than by any seamount effect. At the time of sampling, the MAD-Ridge sampling area was influenced by a young dipole eddy, formed a few weeks and days prior to the cruise ( 1 Nov for the cyclone and 12 Nov for the anticyclone, Vianello et al. (this issue)). The region south of Madagascar is well-known for its eddy field, formed by the interaction between the East Madagascar Current and the land mass of Madagascar (de Ruijter et al., 2004a). The zooplankton abundance and biovolume in the cyclonic eddy were higher than in the anticyclone (excluding station 18). This agrees with previous observations where the cores of cyclonic eddies, in their spinning up phase as in this study, often contain higher zooplankton concentrations than their surrounding waters due to the upwelling taking place (e.g. Huggett, 2014; Landry et al., 2008; Lebourges-Dhaussy et al., 2014; Noyon et al., 2019; Riandey et al., 2005). Cores of anticyclonic eddies usually have less plankton due to downwelling occurring during the spinning up phase. Yet other factors influence eddy productivity such as the state of the eddy (spinning up or down), as well as the origin of the eddy and its interaction with surrounding water masses, especially coastal waters which are enriched in biological material, more than offshore waters (e. g. Gaube et al., 2014; Huggett, 
2014; Landry et al., 2008; Mackas et al., 2005; Sabarros et al., 2009; Strzelecki et al., 2007). It is difficult to characterise the limits of eddies as edges are more a gradient than a clear boundary. The stations classified as "transition" $(6,14$ and 15) were located at the border of the anticyclone and revealed intermediate concentrations of zooplankton, slightly higher than inside the anticyclone itself. This matches previous observations showing anticyclone edges being richer than their core due to either upwelling occurring on the edges or transient filaments of enriched waters wrapping themselves around eddies (Bakun, 2006; Holliday et al., 2011; Sabarros et al., 2009).

Station 18 which was in the anticyclone was sampled at dusk due to a sampling delay, thus the high abundance and biovolume, visible in the upper $100 \mathrm{~m}$, could be partly attributable to diel vertical migration (DVM). Previous work revealed that mesozooplankton DVM is limited in the SWIO (Huggett, 2014; Noyon et al., 2019). Despite a slight increase in euphausiid biovolume between 25 and $75 \mathrm{~m}$ depth, the slopes at station 18 were similar to the average suggesting that all taxa were present in the water column and not only large diel vertical migrators. Hence, we cannot exclude that the high biovolume of zooplankton could also be due to natural patchiness. This station was $27 \mathrm{~km}$ south of the seamount, so it is difficult to conclude whether the seamount had an impact here. It is most likely not due to local enrichment as none was detected at MAD-Ridge (Demarcq et al., this issue) and there were no retention mechanisms over the seamount. High concentrations of zooplankton could be due to reduced predation pressure but considering that all the other stations had lower concentrations than at station 18 , this would suggest that the water mass sampled at station 18 would have been the only one to not suffer from excessive predation pressure linked to the seamount. Gaps in zooplankton abundance have more often observed around seamounts (Genin et al., 1994; Haury et al., 2000).

Most stations at MAD-Ridge were located within an anticyclone and showed low zooplankton biovolume and similar size spectra, with the exception of four stations. These four stations had similar total abundance, biovolume and taxonomic composition, but showed differences in their size spectra with stations 29 and 30 having a peak of biovolume in the small sized organisms $(0.7$ to $1.5 \mathrm{~mm})$ while stations 2 and 18 had a peak in the larger ones ( 1.5 to $3 \mathrm{~mm} \mathrm{ESD)}$ ). The influence on zooplankton composition by cross-shelf transport and offshore flowing filaments that may interact with eddies has already been reported for 
this region (Noyon et al., 2019). In the latter study, microscope analysis showed that the shelf was dominated by Paracalanus spp and small Calanoid copepodites, both of which are small sized copepods which could be what was observed at these northern stations. Station 30 showed an even stronger proportion of small organisms (Oithona spp and small calanoids) with the steepest of all slopes measured. The ocean colour images of 20-22 November, just prior to sampling, show this station being in the middle of a filament of high productivity which may explain the difference with station 29 . The offshore stations were characterised by different zooplankton communities with larger copepods, due to either a different species composition or an older cohort comprised of older and larger Calanoid stages, compared to the shelf.

Zooplankton was concentrated in the upper $100 \mathrm{~m}$ of the water column and sometimes even more so in the upper $30 \mathrm{~m}$. The lack of correlation between $\mathrm{Chl} a$ and zooplankton concentration at any depth, however, suggests that the zooplankton are most likely not only feeding on phytoplankton (Calbet, 2001), or that the turn-over in these waters is high enough that the phytoplankton is grazed as soon it is produced, preventing biomass from accumulating.

Somewhat surprisingly, the NBSS slopes at MAD-Ridge were highly variable with depth and did not show any correlation with the distribution of $\mathrm{Chl} a$. Few studies have explored the relationship between zooplankton NBSS and depth, but Suthers et al. (2006) observed steeper slopes around the thermocline (30 or 60m). In Lebourges-Dhaussy et al. (2014), although they do not show the NBSS at different depths, they did notice an increase in the small size classes 0.4 to $1 \mathrm{~mm}$ and $>2 \mathrm{~mm}$ ESD in proximity to the DCM in cyclonic eddies in the Mozambique Channel. We observed steeper NBSS slopes at the depth of the DCM within the cyclonic eddy (at station 2 and the adjacent station 6), whereas in the anticyclone most of the steepest slopes were located in the shallowest net of the Multinet ( 25 to $30 \mathrm{~m}$ ). The variability of the slopes in our study could also be a consequence of the rarity and patchiness of large migrating zooplankton which are able to enter and leave the system (Rodriguez and Mullin, 1986). NBSS slopes might be impacted strongly by the occurrence of these rare large specimens.

4.2.2. La Pérouse 
The zooplankton at La Pérouse was highly variable in terms of abundance and biovolume and seemed very patchy. This could be due to natural patchiness or a topographic effect, but was also likely influenced by the change in circulation during the cruise. The detailed vertical current profiles (Marsac et al., this issue) revealed a prevalent surface current in a north-north-west direction but a change of direction towards the south at the end of the cruise when stations 23 and 24 were sampled. Hence stations 4 and 9 (without the one trachymedusa) were upstream of the seamount at the time of sampling and had low zooplankton abundance, while stations 3 and 6 were located downstream of the seamount and had high zooplankton abundance, suggesting a possible retention or aggregation effect in the lee of the seamount. Previous observations of greater abundance of zooplankton downstream from seamounts are hypothesised to be due to stronger currents above the seamount "pushing" the zooplankton downstream (Genin, 2004; Pitcher et al., 2007). However, due to the small sample size in our study, we cannot conclude with any certainty that this downstream peak in abundance was an actual seamount effect.

\subsubsection{Walters Shoal}

We could not do an "on versus off seamount" comparison at Walters Shoal, not having any samples located at some distance from the seamount due to ship time constraints. Nonetheless, the stations sampled were located all around the seamount and at different bottom depths. The main flow around Walters Shoal was extremely low and variable (Demarcq et al., this issue), making it impossible to identify one side as being the lee of the seamount. The zooplankton abundance was low everywhere except at station 14 which had a similar abundance to stations located in the anticyclone at MAD-Ridge, as well as a similar biovolume size spectrum. Station 1, which was sampled adjacent to station 14 in the same "canyon" on the south-west of the seamount, also had slightly greater abundance and biovolume. This deep break in the topography could provide a shelter for organisms which may explain the slight increase in zooplankton abundance. Unfortunately, no ADCP data were available to confirm a possible convection cell in this location.

We cannot reject the hypothesis that the low zooplankton abundance at all the Walters Shoal stations could be the result of increased predation pressure linked to the presence of the seamount. Demarcq et al. (this issue) emphasised that of the three seamounts, Walters Shoal is the only one with a significant enrichment index. However, backscattering data do 
not seem to show any major differences in the response at $38 \mathrm{kHz}$ away from or close to the seamount (unpublished data, G. Roudaut).

\subsection{Concluding remarks}

Overall the zooplankton communities over the seamounts studied were comparable to those in the surrounding waters without any clear seamount effect. The classic hypothesis of enhanced plankton densities around seamounts relies on the presence of a retention mechanism, induced by the topography, which would retain upwelled or advected biomass (Rogers, 1994). However, there was no indication of a Taylor column at any of the seamounts studied here (Annasawmy et al., this issue; Demarcq et al., this issue). Other hypotheses and observations suggest that seamounts have less zooplankton than the surrounding waters due to an increased predation pressure (Genin, 2004; Martin and Christiansen, 2009; Pitcher et al., 2007; Rogers, 1994). At MAD-Ridge, a high acoustic density was measured on the flanks of the seamount during the cruise, suggesting fish aggregation (Annasawmy et al., this issue), but the amount of zooplankton was not significantly different close to or distant from the seamount. Here, the cyclonic eddy and the influence of the shelf had a greater impact on the zooplankton communities than the seamount itself. At La Pérouse, as discussed above and in Marsac et al (this issue), the seamount might have had a small impact on zooplankton at a localised spatial scale with an enhanced biomass in the lee side of the seamount, however this conclusion is based on only two observations and should be investigated further. At Walters Shoal the season most likely had a stronger effect on the zooplankton community than the seamount itself, but the lack of samples at some distance from the seamount made it difficult to draw firm conclusions.

In a recent review, Rogers (2018) acknowledged that many studies on zooplankton did not detect any seamount effect, and that amongst the few studies which did find an effect, a low zooplankton abundance was measured, mostly due to increased predation and topography blockage. In theory, migrating organisms can become trapped on top of seamounts during their descent at dawn. This would either lead to a local accumulation of zooplankton or attract predators and thus result in reduced zooplankton abundance, leading to the formation of "gaps" in the zooplankton distribution. This hypothesis is difficult to test with traditional plankton net as it is too risky to sample very close to the 
bottom over abrupt topography. With the emergence of new technology, optical or acoustic tools such as the Underwater Vision Profiler (Picheral et al., 2010), the zooplankton visualization and imaging system (Bi et al., 2015) or the Acoustic Zooplankton Fish Profiler (Lemon et al., 2012) could be deployed close to the bottom or moored, to convincingly detect this kind of phenomenon (Hosegood et al., 2019, pers. comm.). However, it is likely that only large zooplankton will be impacted by such bottom-trapping in the SWIO, as smaller ones do not seem to perform strong vertical migrations (Huggett, 2014; Martin and Christiansen, 2009; Noyon et al., 2019), and only at shallow seamounts with a summit within the range covered by zooplankton migrations.

\section{Acknowledgments}

The authors would like to thank the anonymous reviewers as well as Hervé Demarcq for his help with the remote sensing products. We also thank the crew and scientists who worked on the RV Antea. All cruises were supported by the Flotte Océanographique Française (French Oceanographic Fleet) and IRD regarding the logistics on the RV Antea. Additional funding was received from Région Reunion (Réunion Regional Council) for La Pérouse cruise, and from the Fonds Français pour l'Environnement Mondial (FFEM) as part of the FFEMSWIO project on Areas Beyond National Jurisdiction (ABNJ) of the South West Indian Ocean for MAD-Ridge cruise. Zo Rasoloarijao received a MSc bursary from the South African National Research Foundation (NRF).

\section{References}

Annasawmy, A., Ternon, J.F., Lebourges-Dhaussy, A., Roudaut, G., Herbette, S., Ménard, F., Cotel, P., Marsac, F., this issue. Micronekton distribution as influenced by mesoscale eddies, Madagascar shelf and shallow seamounts in the south-western Indian Ocean: An acoustic approach.

Bakun, A., 2006. Fronts and eddies as key structures in the habitat of marine fish larvae: opportunity, adaptive response and competitive advantage. Sci. Mar. 70, 105-122.

Barber, R.T., Hiscock, M.R., 2006. A rising tide lifts all phytoplankton: Growth response of other phytoplankton taxa in diatom-dominated blooms. Global Biogeochem. Cycles 20, GB4S03. https://doi.org/10.1029/2006GB002726

Basedow, S.L., Tande, K.S., Zhou, M., 2010. Biovolume spectrum theories applied: spatial patterns of trophic levels within a mesozooplankton community at the polar front. J. Plankton Res. 32, 1105-1119. https://doi.org/10.1093/plankt/fbp110

Bergmann, C., 1847. Über die Verhältnisse der Wärmeökonomie der Thiere zu ihrer Größe. 
Bi, H., Guo, Z., Benfield, M.C., Fan, C., Ford, M., Shahrestani, S., Sieracki, J.M., 2015. A SemiAutomated Image Analysis Procedure for In Situ Plankton Imaging Systems. PLOS ONE 10, e0127121. https://doi.org/10.1371/journal.pone.0127121

Blackburn, T.M., Gaston, K.J., Loder, N., 1999. Geographic gradients in body size: a clarification of Bergmann's rule. Divers. Distrib. 5, 165-174. https://doi.org/10.1046/j.14724642.1999.00046.x

Brown, J.H., Gillooly, J.F., Allen, A.P., Savage, V.M., West, G.B., 2004. Toward a metabolic theory of ecology. Ecology 1771-1789. https://doi.org/10.1890/03-9000@10.1002/(ISSN)19399170.MacArthurAward

Calbet, A., 2001. Mesozooplankton Grazing Effect on Primary Production: A Global Comparative Analysis in Marine Ecosystems. Limnol. Oceanogr. 46, 1824-1830.

Campos, A., Lopes, P., Fonseca, P., Figueiredo, I., Henriques, V., Gouveia, N., Delgado, J., Gouveia, L., Amorim, A., Araujo, G., Drago, T., dos Santos, A., 2019. Portuguese fisheries in seamounts of Madeira-Tore (NE Atlantic). Marine Policy 99, 50-57. https://doi.org/10.1016/j.marpol.2018.10.005

Carmo, V., Santos, M., Menezes, G.M., Loureiro, C.M., Lambardi, P., Martins, A., 2013. Variability of zooplankton communities at Condor seamount and surrounding areas, Azores (NE Atlantic). Deep Sea Res. Part II Top. Stud. Oceanogr., An Integrated Approach for Studying Seamounts: CONDOR Observatory 98, 63-74. https://doi.org/10.1016/j.dsr2.2013.08.007

Chapman, D.C., Haidvogel, D.B., 1992. Formation of Taylor caps over a tall isolated seamount in a stratified ocean. Geophysical \& Astrophysical Fluid Dynamics 64, 31-65. https://doi.org/10.1080/03091929208228084

Dai, L., Li, C., Yang, G., Sun, X., 2016. Zooplankton abundance, biovolume and size spectra at western boundary currents in the subtropical North Pacific during winter 2012. J. Marine Syst. 155, 73-83. https://doi.org/10.1016/j.jmarsys.2015.11.004

de Ruijter, W.P.M., Aken, H.M. van, Beier, E.J., Lutjeharms, J.R.E., Matano, R.P., Schouten, M.W., 2004a. Eddies and dipoles around South Madagascar: formation, pathways and large-scale impact. Deep Sea Res. Part I Oceanogr. Res. Pap. 51, 383-400. https://doi.org/10.1016/j.dsr.2003.10.011

de Ruijter, W.P.M., Aken, H.M. van, Beier, E.J., Lutjeharms, J.R.E., Matano, R.P., Schouten, M.W., 2004b. Eddies and dipoles around South Madagascar: formation, pathways and large-scale impact. Deep Sea Res. Part I Oceanogr. Res. Pap. 51, 383-400. https://doi.org/10.1016/j.dsr.2003.10.011

Denda, A., Christiansen, B., 2014. Zooplankton distribution patterns at two seamounts in the subtropical and tropical NE Atlantic. Marine Ecology 35, 159-179. https://doi.org/10.1111/maec.12065

Dower, J.F., Mackas, D.L., 1996. "Seamount effects" in the zooplankton community near Cobb Seamount. Deep Sea Res. Part I Oceanogr. Res. Pap. 43, 837-858. https://doi.org/10.1016/0967-0637(96)00040-4

Dufois, F., Hardman-Mountford, N.J., Greenwood, J., Richardson, A.J., Feng, M., Herbette, S., Matear, R., 2014. Impact of eddies on surface chlorophyll in the South Indian Ocean. J. Geophys. Res. Oceans 119, 8061-8077. https://doi.org/10.1002/2014JC010164

Frederick, L., Escribano, R., Morales, C.E., Hormazabal, S., Medellín-Mora, J., 2018. Mesozooplankton respiration and community structure in a seamount region of the eastern South Pacific. Deep Sea Res. Part I Oceanogr. Res. Pap. 135, 74-87. https://doi.org/10.1016/j.dsr.2018.03.008

García-Comas, C., Chang, C.-Y., Ye, L., Sastri, A.R., Lee, Y.-C., Gong, G.-C., Hsieh, C., 2014. Mesozooplankton size structure in response to environmental conditions in the East China Sea: How much does size spectra theory fit empirical data of a dynamic coastal area? Prog. Oceanogr., Recent Developments In Oceanography of the Asian Marginal Seas 121, 141-157. https://doi.org/10.1016/j.pocean.2013.10.010 
García-Comas Carmen, Sastri Akash R., Ye Lin, Chang Chun-Yi, Lin Fan-Sian, Su Min-Sian, Gong GwoChing, Hsieh Chih-hao, 2016. Prey size diversity hinders biomass trophic transfer and predator size diversity promotes it in planktonic communities. P. Roy. Soc. B-Biol. Sci. 283, 20152129. https://doi.org/10.1098/rspb.2015.2129

Gasol, J.M., Giorgio, P.A. del, Duarte, C.M., 1997. Biomass distribution in marine planktonic communities. Limnol. Oceanogr. 42, 1353-1363. https://doi.org/10.4319/lo.1997.42.6.1353

Gaube, P., McGillicuddy, D.J., Chelton, D.B., Behrenfeld, M.J., Strutton, P.G., 2014. Regional variations in the influence of mesoscale eddies on near-surface chlorophyll. J. Geophys. Res. Oceans 119, 8195-8220. https://doi.org/10.1002/2014JC010111

Genin, A., 2004. Bio-physical coupling in the formation of zooplankton and fish aggregations over abrupt topographies. J. Marine Syst. 50, 3-20. https://doi.org/10.1016/j.jmarsys.2003.10.008

Genin, A., Greene, C., Haury, L., Wiebe, P., Gal, G., Kaartvedt, S., Meir, E., Fey, C., Dawson, J., 1994. Zooplankton patch dynamics: daily gap formation over abrupt topography. Deep Sea Res. Part I Oceanogr. Res. Pap. 41, 941-951. https://doi.org/10.1016/0967-0637(94)90085-X

Giering, S.L.C., Wells, S.R., Mayers, K.M.J., Schuster, H., Cornwell, L., Fileman, E.S., Atkinson, A., Cook, K.B., Preece, C., Mayor, D.J., 2018. Seasonal variation of zooplankton community structure and trophic position in the Celtic Sea: A stable isotope and biovolume spectrum approach. Prog. Oceanogr. https://doi.org/10.1016/j.pocean.2018.03.012

Gillooly, J.F., Brown, J.H., West, G.B., Savage, V.M., Charnov, E.L., 2001. Effects of Size and Temperature on Metabolic Rate. Science 293, 2248-2251. https://doi.org/10.1126/science.1061967

Gorsky, G., Ohman, M.D., Picheral, M., Gasparini, S., Stemmann, L., Romagnan, J.-B., Cawood, A., Pesant, S., García-Comas, C., Prejger, F., 2010. Digital zooplankton image analysis using the ZooScan integrated system. J. Plankton Res. 32, 285-303. https://doi.org/10.1093/plankt/fbp124

Halo, I., Penven, P., Backeberg, B., Ansorge, I., Shillington, F., Roman, R., 2014. Mesoscale eddy variability in the southern extension of the East Madagascar Current: Seasonal cycle, energy conversion terms, and eddy mean properties. J. Geophys. Res. Oceans 119, 7324-7356. https://doi.org/10.1002/2014JC009820

Haury, L., Fey, C., Gal, G., Hobday, A., Genin, A., 1995. Copepod carcasses in the ocean. I. Over seamounts. Mar. Ecol. Prog. Ser. 123, 57-63. https://doi.org/10.3354/meps123057

Haury, L., Fey, C., Newland, C., Genin, A., 2000. Zooplankton distribution around four eastern North Pacific seamounts. Prog. Oceanogr. 45, 69-105. https://doi.org/10.1016/S00796611(99)00051-8

Hirst, A.G., Bunker, A.J., 2003. Growth of marine planktonic copepods: global rates and patterns in relation to chlorophyll $a$, temperature and body weight. Limnol. Oceanogr. 48, 1988-2010.

Holliday, D., Beckley, L.E., Olivar, M.P., 2011. Incorporation of larval fishes into a developing anticyclonic eddy of the Leeuwin Current off south-western Australia. J. Plankton Res. 33, 16961708. https://doi.org/10.1093/plankt/fbr064

Hosegood, P.J., Nimmo-Smith, W.A.M., Proud, R., Adams, K., Brierley, A.S., 2019. Internal lee waves and baroclinic bores over a tropical seamount shark 'hot-spot.' Prog. Oceanogr. 172, 34-50. https://doi.org/10.1016/j.pocean.2019.01.010

Huggett, J.A., 2014. Mesoscale distribution and community composition of zooplankton in the Mozambique Channel. Deep Sea Res. Part II Top. Stud. Oceanogr., The Mozambique Channel: Mesoscale Dynamics and Ecosystem Responses 100, 119-135. https://doi.org/10.1016/j.dsr2.2013.10.021

Huntley, M.E., Lopez, M.D., 1992. Temperature-dependent production of marine copepods: a global synthesis. Am. Nat 140, 201-242. https://doi.org/10.1086/285410

Irigoien, X., Klevjer, T.A., Røstad, A., Martinez, U., Boyra, G., Acuña, J.L., Bode, A., Echevarria, F., Gonzalez-Gordillo, J.I., Hernandez-Leon, S., Agusti, S., Aksnes, D.L., Duarte, C.M., Kaartvedt, 
S., 2014. Large mesopelagic fishes biomass and trophic efficiency in the open ocean. Nat Commun 5, 1-10. https://doi.org/10.1038/ncomms4271

Landry, M.R., Decima, M., Simmons, M.P., Hannides, C.C.S., Daniels, E., 2008. Mesozooplankton biomass and grazing responses to Cyclone Opal, a subtropical mesoscale eddy. Deep Sea Res. Part II Top. Stud. Oceanogr., Mesoscale Physical-Biological-Biogeochemical Linkages in the Open Ocean: Results from the E-FLUX and EDDIES Programs 55, 1378-1388. https://doi.org/10.1016/j.dsr2.2008.01.005

Lebourges-Dhaussy, A., Huggett, J., Ockhuis, S., Roudaut, G., Josse, E., Verheye, H., 2014. Zooplankton size and distribution within mesoscale structures in the Mozambique Channel: A comparative approach using the TAPS acoustic profiler, a multiple net sampler and ZooScan image analysis. Deep Sea Res. Part II Top. Stud. Oceanogr., The Mozambique Channel: Mesoscale Dynamics and Ecosystem Responses 100, 136-152. https://doi.org/10.1016/j.dsr2.2013.10.022

Lemon, D., Johnston, P., Buermans, J., Loos, E., Borstad, G., Brown, L., 2012. Multiple-frequency moored sonar for continuous observations of zooplankton and fish, in: 2012 Oceans. Presented at the 2012 Oceans, pp. 1-6. https://doi.org/10.1109/OCEANS.2012.6404918

Lemos, A.T., Ghisolfi, R.D.R., Mazzini, P.L.F., 2018. Annual phytoplankton blooming using satellitederived chlorophyll-a data around the Vitória-Trindade Chain, Southeastern Brazil. Deep Sea Res. Part II Top. Stud. Oceanogr. 136, 62-71. https://doi.org/10.1016/j.dsr.2018.04.005

Longhurst, A., 2007. Ecological Geography of the Sea. Elsevier. https://doi.org/10.1016/B978-0-12455521-1.X5000-1

Mackas, D.L., Tsurumi, M., Galbraith, M.D., Yelland, D.R., 2005. Zooplankton distribution and dynamics in a North Pacific Eddy of coastal origin: II. Mechanisms of eddy colonization by and retention of offshore species. Deep Sea Research Part II: Topical Studies in Oceanography 52, 1011-1035. https://doi.org/10.1016/j.dsr2.2005.02.008

Madhupratap, M., 1983. Zooplankton standing stock and diversity along an oceanic track in the western Indian Ocean. Mahasagar 16, 463-467-467.

Marsac, F., Annasawmy, A., Noyon, M., Demarcq, H., Bach, P., Rabearisoa, N., Soria, M., Romanov, E., this issue. Local circulation patterns and biological responses in the vicinity of La Pérouse seamount, northwest of Reunion island, Indian Ocean.

Martin, B., Christiansen, B., 2009. Distribution of zooplankton biomass at three seamounts in the NE Atlantic. Deep Sea Res. Part II Top. Stud. Oceanogr., The Oceanography, Biogeochemistry and Ecology of Two NE Atlantic Seamounts: OASIS 56, 2671-2682. https://doi.org/10.1016/j.dsr2.2008.12.026

Mendonça, A., Arístegui, J., Vilas, J.C., Montero, M.F., Ojeda, A., Espino, M., Martins, A., 2012. Is There a Seamount Effect on Microbial Community Structure and Biomass? The Case Study of Seine and Sedlo Seamounts (Northeast Atlantic). PLoS ONE 7, e29526. https://doi.org/doi.org/10.1371/journal.pone.0029526

Morato, T., Hoyle, S.D., Allain, V., Nicol, S.J., 2010a. Seamounts are hotspots of pelagic biodiversity in the open ocean. PNAS 107, 9707-9711. https://doi.org/10.1073/pnas.0910290107

Morato, T., Pitcher, T.J., Clark, M.R., Menezes, F., Tempera, F., Porteiro, E., Giacomello, E., Santos, R.S., 2010b. Can we protect seamounts for research? A call for conservation. Oceanography 23, 19-199. https://doi.org/doi.org/10.5670/oceanog.2010.71.

Muhling, B.A., Beckley, L.E., Olivar, M.P., 2007. Ichthyoplankton assemblage structure in two mesoscale Leeuwin Current eddies, eastern Indian Ocean. Deep Sea Res. Part II Top. Stud. Oceanogr., The Leeuwin Current and its Eddies 54, 1113-1128. https://doi.org/10.1016/j.dsr2.2006.05.045

Noyon, M., Morris, T., Walker, D., Huggett, J., 2019. Plankton distribution within a young cyclonic eddy off south-western Madagascar. Deep Sea Res. Part II Top. Stud. Oceanogr. 166, 141150. https://doi.org/10.1016/j.dsr2.2018.11.001

Picheral, M., Colin, S., Irison, J.-O., 2017. EcoTaxa, a tool for the taxonomic classification of images. http://ecotaxa.obs-vlfr.fr. [WWW Document]. 
Picheral, M., Guidi, L., Stemmann, L., Karl, D.M., Iddaoud, G., Gorsky, G., 2010. The Underwater Vision Profiler 5: An advanced instrument for high spatial resolution studies of particle size spectra and zooplankton. Limnol. Oceanogr. Methods 8, 462-473. https://doi.org/10.4319/lom.2010.8.462

Pitcher, T.J., Bulman, C., 2007. Raiding the larder: a quantitative evaluation framework and trophic signature for seamount food webs, in: Pitcher, T.J., Morato, T., Hart, P.J.B., Clark, M.R., Haggan, N., Santos, R.S. (Eds), Seamounts: Ecology, Fisheries \& Conservation, Fish and Aquatic Research Series. Blackwell Publishing, Oxford, pp. 282-295. https://doi.org/10.1002/9780470691953

Pitcher, T.J., Morato, T., Hart, P.J.B., Clark, M.R., Haggan, N., Santos, R.S., 2007. Seamounts: Ecology, Fisheries \& Conservation. Blackwell Publishing.

Platt, T., Denman, K., 1977. Organisation in the pelagic ecosystem. Helgoländer wissenschaftliche Meeresuntersuchungen 30, 575. https://doi.org/10.1007/BF02207862

Pollard, R., Read, J., 2017. Circulation, stratification and seamounts in the Southwest Indian Ocean. Deep Sea Res. Part II Top. Stud. Oceanogr., The Pelagic Ecology of Seamounts of the South West Indian Ocean 136, 36-43. https://doi.org/10.1016/j.dsr2.2015.02.018

Quartly, G.D., Buck, J.J.H., Srokosz, M.A., Coward, A.C., 2006. Eddies around Madagascar - The retroflection re-considered. J. Marine Syst. 63, 115-129. https://doi.org/10.1016/j.jmarsys.2006.06.001

Quinones, R.A., Platt, T., Rodríguez, J., 2003. Patterns of biomass-size spectra from oligotrophic waters of the Northwest Atlantic. Prog. Oceanogr., Plankton size-classes, functional groups and ecosystem dynamics 57, 405-427. https://doi.org/10.1016/S0079-6611(03)00108-3

Quintana, X.D., Brucet, S., Boix, D., López-Flores, R., Gascón, S., Badosa, A., Sala, J., Moreno-Amich, R., Egozcue, J.J., 2008. A nonparametric method for the measurement of size diversity with emphasis on data standardization. Limnol. Oceanogr. Methods 6, 75-86. https://doi.org/10.4319/lom.2008.6.75

R Core Team, 2018. R: A Language and Environment for Statistical Computing. R Foundation for Statistical Computing, Vienna.

Riandey, V., Champalbert, G., Carlotti, F., Taupier-Letage, I., Thibault-Botha, D., 2005. Zooplankton distribution related to the hydrodynamic features in the Algerian Basin (western Mediterranean Sea) in summer 1997. Deep Sea Res. Part I Oceanogr. Res. Pap. 52, 20292048. https://doi.org/10.1016/j.dsr.2005.06.004

Roberts, M.J., Marsac, F., Noyon, M., Ternon, J.F., this issue. Ecosystems of three shallow seamounts east and south of Madagascar.

Rodriguez, J., Mullin, M.M., 1986. Relation between biomass and body weight of plankton in a steady state oceanic ecosystem1. Limnol. Oceanogr. 31, 361-370. https://doi.org/10.4319/lo.1986.31.2.0361

Rogers, A.D., 2018. The Biology of Seamounts: 25 Years on, in: Sheppard, C. (Ed.), Advances in Marine Biology. Academic Press, pp. 137-224. https://doi.org/10.1016/bs.amb.2018.06.001

Rogers, A.D., 1994. The Biology of Seamounts, in: Blaxter, J.H.S., Southward, A.J. (Eds.), Advances in Marine Biology. Academic Press, pp. 305-350. https://doi.org/10.1016/S00652881(08)60065-6

Sabarros, P., Ménard, F., Lévénez, J., Tew-Kai, E., Ternon, J., 2009. Mesoscale eddies influence distribution and aggregation patterns of micronekton in the Mozambique Channel. Mar. Ecol. Prog. Ser. 395, 101-107. https://doi.org/10.3354/meps08087

San Martin, E., Irigoien, X., P, H.R., Urrutia, Â.L., Zubkov, M.V., Heywood, J.L., 2006. Variation in the transfer of energy in marine plankton along a productivity gradient in the Atlantic Ocean. Limnol. Oceanogr. 51, 2084-2091. https://doi.org/10.4319/lo.2006.51.5.2084

Säwström, C., Beckley, L.E., Saunders, M.I., Thompson, P.A., Waite, A.M., 2014. The zooplankton prey field for rock lobster phyllosoma larvae in relation to oceanographic features of the south-eastern Indian Ocean. J. Plankton Res. 36, 1003-1016. https://doi.org/10.1093/plankt/fbu019 
Sheldon, R.W., Prakash, A., Sutcliffe, W.H., 1972. The Size Distribution of Particles in the Ocean1. Limnol. Oceanogr. 17, 327-340. https://doi.org/10.4319/lo.1972.17.3.0327

Silvert, W., Platt, T., 1978. Energy flux in the pelagic ecosystem: A time-dependent equation. Limnol. Oceangr. 23, 813-816. https://doi.org/10.4319/lo.1978.23.4.0813

Sourisseau, M., Carlotti, F., 2006. Spatial distribution of zooplankton size spectra on the French continental shelf of the Bay of Biscay during spring 2000 and 2001. J. Geophys. Res. 111. https://doi.org/10.1029/2005JC003063

Sprules, W.G., Barth, L.E., 2015. Surfing the biomass size spectrum: some remarks on history, theory, and application. Can. J. Fish. Aquat. Sci. 73, 477-495. https://doi.org/10.1139/cjfas-20150115

Strzelecki, J., Koslow, J.A., Waite, A., 2007. Comparison of mesozooplankton communities from a pair of warm- and cold-core eddies off the coast of Western Australia. Deep Sea Res. Part II Top. Stud. Oceanogr. 54, 1103-1112. https://doi.org/10.1016/j.dsr2.2007.02.004

Suthers, I.M., Taggart, C.T., Rissik, D., Baird, M.E., 2006. Day and night ichthyoplankton assemblages and zooplankton biomass size spectrum in a deep ocean island wake. Mar. Ecol. Prog. Ser. 322, 225-238. https://doi.org/10.3354/meps322225

Thompson, P.A., Pesant, S., Waite, A.M., 2007. Contrasting the vertical differences in the phytoplankton biology of a dipole pair of eddies in the south-eastern Indian Ocean. Deep Sea Res. Part II Top. Stud. Oceanogr., The Leeuwin Current and its Eddies 54, 1003-1028. https://doi.org/10.1016/j.dsr2.2006.12.009

Vandromme, P., Stemmann, L., Garcì-Comas, C., Berline, L., Sun, X., Gorsky, G., 2012. Assessing biases in computing size spectra of automatically classified zooplankton from imaging systems: A case study with the ZooScan integrated system. Methods in Oceanography 1-2, 3-21. https://doi.org/10.1016/j.mio.2012.06.001

Vianello, P., Ternon, J.F., Herbette, S., Roberts, M.J., this issue. Circulation and hydrography in the vicinity of a shallow seamount on the northern Madagascar Ridge.

Warner, R., 2018. Conservation and Management of Marine Living Resources beyond National Jurisdiction: Filling the Gaps. High Seas Governance 179-194. https://doi.org/10.1163/9789004373303_007

Watt, C., Mitchell, S., Salewski, V., 2010. Bergmann's rule; a concept cluster? Oikos 119, 89-100. https://doi.org/10.1111/j.1600-0706.2009.17959.x

White, M., Bashmachnikov, I., Arístegui, J., Martins, A., 2007. Physical Processes and Seamount Productivity, in: Pitcher, T.J., Morato, T., Hart, P.J.B., Clark, M.R., Haggan, N., Santos, R.S. (Eds), Seamounts: Ecology, Fisheries \& Conservation, Fish and Aquatic Research Series. Blackwell Publishing, Oxford, pp. 62-84. https://doi.org/10.1002/9780470691953.ch4 Zhou, M., 2006. What determines the slope of a plankton biomass spectrum? J. Plankton Res. 28, 437-448. https://doi.org/10.1093/plankt/fbi119

Zhou, M., Huntley, M.E., 1997. Population dynamics theory of plankton based on biomass spectra. Mar. Ecol. Prog. Ser. 159, 61-73. https://doi.org/10.3354/meps159061

Zhou, M., Zhu, Y., Peterson, J.O., 2004. In situ growth and mortality of mesozooplankton during the austral fall and winter in Marguerite Bay and its vicinity. Deep Sea Res. Part II Top. Stud. Oceanogr., Integrated Ecosystem Studies of Western Antarctic Peninsula Continental Shelf Waters and Related Southern Ocean Regions 51, 2099-2118. https://doi.org/10.1016/j.dsr2.2004.07.008 
Fig. 1: Map of the seasonal variability of the surface Chlorophyll a concentration (MODIS-Aqua 4-km resolution) using the coefficient of variation of the fortnightly climatology series from 2003-2018, covering the three study sites (red squares) with detailed bathymetry of the three seamounts studied with the location of the stations sampled (empty circle: "on" seamount; black circle: "off" seamount)

Fig. 2: Map of the composite sea surface chlorophyll $a$ concentration $\left(\mathrm{mg} \mathrm{m}^{-3}\right)$ and the sea surface height anomalies (white, black and oranges lines, in $\mathrm{cm}$ ) on the 20-22 November 2016, during the MAD-Ridge cruise. The white dots correspond to the stations sampled during these dates while the red dots are the stations sampled during the MAD-Ridge cruise. White lines correspond to the cyclonic eddy and orange lines to the anticyclonic eddy

1038

1039

1040

1041

1042

1043

1044

1045

1046

1047

1048

1049

1050

1051

1052

1053

1054

1055

1056

1057

1058

1059

1060

1061

1062

1063

1064

1065

1066

1067

1068

1069

Fig. 3: Monthly variability (average and standard deviation, vertical line) of Sea Surface Temperature (top, ${ }^{\circ} \mathrm{C}$ ) and surface Chlorophyll a concentration $\left(\mathrm{mg} \mathrm{m}^{-3}\right.$ ) at the three seamounts (data from MODIS-Aqua 2003-2017). Grey boxes indicate each cruise

Fig. 4. Normalised Biomass Size Spectrum at the three seamounts La Pérouse, MAD-Ridge and Walters Shoal

Fig. 5: Biovolume $\left(\mathrm{mm}^{3} \mathrm{~m}^{-3}\right)$ spectrum of Calanoida, Chaetognaths and global (all taxa together, panels $a, b$ and $c$ ) of all the stations sampled during the three cruises (LP: La Pérouse, panels $d, e, f$; MR: MAD-Ridge - panels $g$ to I; WS: Walters Shoal - panels $m$ to o). The MAD-Ridge samples are presented in two horizontal blocks with all the stations that differ from each other in panels $g$ to $i$ and the ones that are similar to each other in panels $\mathrm{j}$ to $\mathrm{l}$ ). The upper panels $(\mathrm{a}, \mathrm{b}, \mathrm{c})$ represent the averaged biovolume per bin of the stations grouped as per the lower panels

Fig. 6: Total abundance (left) and NBSS slopes (right) at La Pérouse

Fig. 7: Abundance (ind $\mathrm{m}^{-3}$, left panel) and biovolume $\left(\mathrm{mm}^{3} \mathrm{~m}^{-3}\right.$, right) per size classes $(0.2-0.3-0.5$ $-1-2-4 \mathrm{~mm}$ and more than $4 \mathrm{~mm}$ equivalent spherical diameter) at the 3 seamounts. Note that due to the low abundance and biovolume at the three seamounts, the $y$-axis scales are sometimes different between the panels

Fig. 8: Total abundance (left) and NBSS slopes (right) at MAD-Ridge. The upper panel shows the whole area sampled, and the lower panel shows a zoom on the seamount. Note legends are different in each panel

Fig. 9. Vertical distribution of zooplankton total abundance, total biovolume (BV), NBSS slope and biovolume of small Calanoida ( $<1 \mathrm{~mm}$ ESD), Chaetognatha, and total biovolume of organisms larger than $2.7 \mathrm{~mm}$ ESD on the West - East transect (left, stations 2 to 15) and South - North transect (right, stations 16 to 31). The size of the circles is proportional to the magnitude of the parameter represented (similar to the colour bar). The black dotted line represents the depth of the Deep Chlorophyll maximum (DCM)

Fig. 10: Total abundance (left) and NBSS slopes (right) at Walters Shoal

Fig. 11: Ordination plot (non-metric multidimensional scaling, nMDS) of all the stations from the three cruises using the biovolume of zooplankton $\left(\mathrm{mm}^{3} \mathrm{~m}^{-3}\right)$ in all the bin sizes of the NBSS as well as the size diversity index, the slope, linear fit and intercept of the NBSS. Stations have different symbols according to the cruise (see legend). Note that MAD-Ridge was sub-divided into two sets of stations: dark triangles for the stations within the anticyclone (AC), white triangles for the others. Stations are named according to the cruise ( $P$ for La Pérouse, $M$ for MAD-Ridge and $W$ for Walters 
1070 Shoal) followed by the numbers as per Figure 1. The bin sizes used (red crosses) are named using the 1071 abbreviation "BV" for biovolume followed by the middle of the bin size in mm ESD. The red dotted 1072 line links the bin size in order. Green arrows represent the significant environmental explanatory 1073 variables $(p>0.05)$, plotted on top of the ordination: Sea Surface Temperature (SST) and depth of 1074 the Deep Chlorophyll a Maximum (DCM) 
Journal Pre-proof

Table 1: Environmental variables measured during the three cruises

\begin{tabular}{lccccccccc}
\hline & \multicolumn{3}{c}{ La Pérouse } & \multicolumn{3}{c}{ MAD-Ridge } & \multicolumn{3}{c}{ Walters Shoal } \\
& \multicolumn{3}{c}{$n=10$} & \multicolumn{3}{c}{$n=23$} & \multicolumn{3}{c}{$n=13$} \\
\cline { 2 - 11 } & avg. & \pm & std & avg. & \pm & std & avg. & \pm & std \\
\hline Sea Surface Temperature $\left({ }^{\circ} \mathrm{C}\right)$ & 23.6 & \pm & 0.7 & 24.5 & \pm & 0.2 & 20.5 & \pm & 0.4 \\
Mixed Layer Depth $(\mathrm{m})$ & 59 & \pm & 22 & 51 & \pm & 26 & 41 & \pm & 17 \\
Deep Chl a Maximum Depth $(\mathrm{m})$ & 105 & \pm & 23 & 106 & \pm & 29 & 37 & \pm & 10 \\
Integrated Chl a $\left(\mathrm{mg} \mathrm{m}^{-3}\right)$ & 20.23 & \pm & 3.51 & 20.76 & \pm & 3.06 & 23.07 & \pm & 4.56 \\
Chl a at Deep Chl a Max $\left(\mathrm{mg} \mathrm{m}^{-3}\right)$ & 0.314 & \pm & 0.083 & 0.300 & \pm & 0.134 & 0.239 & \pm & 0.039 \\
Nutricline Depth $(\mathrm{m})$ & 112 & \pm & 22 & 119 & \pm & 34 & 53 & \pm & 11 \\
\hline
\end{tabular}


Table 2: Abundance and biovolume of zooplankton collected during the three cruises and Normalised Biovolume Size Spectrum (NBSS) parameters. The last three lines ('all') correspond to the parameters of the global NBSS calculated for each seamount using all the stations together.

\begin{tabular}{|c|c|c|c|c|c|c|c|c|c|}
\hline & \multicolumn{3}{|c|}{$\begin{array}{c}\text { La Pérouse } \\
n=10\end{array}$} & \multicolumn{3}{|c|}{$\begin{array}{c}\text { MAD-Ridge } \\
n=23\end{array}$} & \multicolumn{3}{|c|}{$\begin{array}{c}\text { Walters Shoal } \\
n=13\end{array}$} \\
\hline & avg. & \pm & std & avg. & \pm & std & avg. & \pm & std \\
\hline Abundance (ind $m^{-3}$ ) & 201.2 & \pm & 98.2 & 204.6 & \pm & $\overline{90.0}$ & 60.8 & \pm & 53.4 \\
\hline Biovolume $\left(\mathrm{mm}^{3} \mathrm{~m}^{-3}\right)$ & 42.81 & \pm & 15.14 & 45.64 & \pm & 20.92 & 12.69 & \pm & 8.27 \\
\hline NBSS slope & -0.89 & \pm & 0.15 & -1.00 & \pm & 0.09 & -0.79 & \pm & 0.09 \\
\hline NBSS intercept & 0.59 & \pm & 0.18 & 0.50 & \pm & 0.17 & -0.20 & \pm & 0.32 \\
\hline Size diversity Index & 2.27 & \pm & 0.05 & 2.34 & \pm & 0.05 & 2.18 & \pm & 0.05 \\
\hline NBSS slope - all & \multicolumn{3}{|c|}{-0.93} & \multicolumn{3}{|c|}{-1.00} & \multicolumn{3}{|c|}{-0.78} \\
\hline NBSS intercept - all & \multicolumn{3}{|c|}{0.57} & \multicolumn{3}{|c|}{0.50} & \multicolumn{3}{|c|}{-0.18} \\
\hline NBSS linear fit - all & \multicolumn{3}{|c|}{0.93} & \multicolumn{3}{|c|}{0.94} & \multicolumn{3}{|c|}{0.78} \\
\hline
\end{tabular}


Table 3: Abundance (ind $\mathrm{m}^{-3}$ ) of all taxa for all the stations at each studied seamount: average \pm standard deviation (avg \pm std) and percentage

\begin{tabular}{|c|c|c|c|c|c|c|c|c|c|c|c|c|}
\hline & \multicolumn{4}{|c|}{$\begin{array}{l}\text { La Pérouse } \\
\qquad n=10\end{array}$} & \multicolumn{4}{|c|}{$\begin{array}{c}\text { MAD-Ridge } \\
n=23\end{array}$} & \multicolumn{4}{|c|}{$\begin{array}{c}\text { Walters Shoal } \\
n=13\end{array}$} \\
\hline & avg. & \pm & std & $\%$ & avg. & \pm & std & $\%$ & avg. & \pm & std & $\%$ \\
\hline Calanoida & 86.5 & \pm & 46.1 & 42.7 & 83.1 & \pm & 49.7 & 39.1 & 31.6 & \pm & 34.0 & 46.5 \\
\hline Oithonidae & 21.7 & \pm & 12.9 & 10.3 & 17.7 & \pm & 5.8 & 9.1 & 7.4 & \pm & 7.3 & 12.6 \\
\hline Oncaeidae & 19.4 & \pm & 12.0 & 9.1 & 17.7 & \pm & 10.1 & 8.4 & 1.7 & \pm & 5.7 & 1.1 \\
\hline Other copepoda & 20.5 & \pm & 7.8 & 10.5 & 25.2 & \pm & 8.0 & 13.0 & 5.0 & \pm & 4.9 & 8.8 \\
\hline Appendicularia & 8.7 & \pm & 3.8 & 4.8 & 10.9 & \pm & 5.9 & 5.2 & 2.4 & \pm & 1.6 & 5.0 \\
\hline Chaetognatha & 11.5 & \pm & 4.0 & 6.2 & 9.3 & \pm & 2.2 & 4.9 & 2.4 & \pm & 1.3 & 5.8 \\
\hline Amphipoda & 0.8 & \pm & 0.8 & 0.5 & 1.0 & \pm & 0.4 & 0.5 & 0.1 & \pm & 0.1 & 0.2 \\
\hline Euphausiacea & 1.3 & \pm & 0.9 & 0.7 & 1.2 & \pm & 0.8 & 0.6 & 0.1 & \pm & 0.1 & 0.2 \\
\hline Decapoda larvae & 0.5 & \pm & 0.7 & 0.2 & 0.4 & \pm & 0.2 & 0.2 & 0.3 & \pm & 0.4 & 0.4 \\
\hline Other crustaceans & 12.6 & \pm & 8.5 & 6.1 & 13.2 & \pm & 6.5 & 6.4 & 1.8 & \pm & 2.9 & 2.8 \\
\hline Gelatinous zooplankton & 1.6 & \pm & 0.6 & 0.9 & 2.7 & \pm & 1.2 & 1.4 & 0.3 & \pm & 0.4 & 0.5 \\
\hline Harosa & 5.2 & \pm & 4.0 & 2.5 & 10.5 & \pm & 5.0 & 5.4 & 1.9 & \pm & 1.0 & 4.6 \\
\hline Other zooplankton & 10.9 & \pm & 8.5 & 5.3 & 11.8 & \pm & 6.5 & 5.7 & 5.8 & \pm & 4.2 & 11.4 \\
\hline
\end{tabular}


Table 4: Biovolume $\left(\mathrm{mm}^{3} \mathrm{~m}^{-3}\right)$ of all the taxa for all the stations at all three seamounts: average \pm standard deviation (avg \pm std) and percentage

\begin{tabular}{|c|c|c|c|c|c|c|c|c|c|c|c|c|}
\hline & \multicolumn{4}{|c|}{ La Pérouse } & \multicolumn{4}{|c|}{ MAD-Ridge } & \multicolumn{4}{|c|}{ Walters Shoal } \\
\hline & avg. & \pm & std & $\%$ & avg. & \pm & std & $\%$ & avg. & \pm & std & $\%$ \\
\hline Calanoida & 13.94 & \pm & 5.43 & 33.8 & 15.18 & \pm & 12.52 & 30.4 & 1.96 & \pm & 2.46 & 13.6 \\
\hline Oithonidae & 0.85 & \pm & 0.47 & 2.1 & 0.64 & \pm & 0.21 & 1.5 & 0.16 & \pm & 0.14 & 1.3 \\
\hline Oncaeidae & 0.87 & \pm & 0.51 & 2.1 & 0.83 & \pm & 0.57 & 1.8 & 0.05 & \pm & 0.17 & 0.2 \\
\hline Other copepoda & 2.21 & \pm & 1.62 & 5.0 & 2.31 & \pm & 1.02 & 5.4 & 0.20 & \pm & 0.17 & 2.1 \\
\hline Appendicularia & 0.60 & \pm & 0.29 & 1.7 & 0.82 & \pm & 0.66 & 1.7 & 0.29 & \pm & 0.59 & 0.9 \\
\hline Chaetognatha & 10.04 & \pm & 3.93 & 23.6 & 7.93 & \pm & 3.79 & 18.6 & 4.40 & \pm & 3.97 & 40.2 \\
\hline Amphipoda & 1.11 & \pm & 1.50 & 2.4 & 1.74 & \pm & 1.48 & 4.2 & 0.29 & \pm & 0.59 & 2.0 \\
\hline Euphausiacea & 3.16 & \pm & 3.46 & 6.7 & 3.32 & \pm & 3.77 & 7.1 & 2.74 & \pm & 4.25 & 19.6 \\
\hline Decapoda larvae & 1.30 & \pm & 1.55 & 2.8 & 1.67 & \pm & 2.43 & 3.6 & 0.55 & \pm & 0.91 & 3.9 \\
\hline Other crustaceans & 1.23 & \pm & 0.76 & 2.7 & 1.52 & \pm & 1.10 & 3.3 & 0.11 & \pm & 0.18 & 0.9 \\
\hline Gelatinous zooplankton & 3.65 & \pm & 2.93 & 8.3 & 5.92 & \pm & 4.02 & 14.1 & 0.71 & \pm & 1.27 & 4.7 \\
\hline Harosa & 0.19 & \pm & 0.13 & 0.4 & 0.54 & \pm & 0.21 & 1.3 & 0.08 & \pm & 0.03 & 0.9 \\
\hline Other zooplankton & 3.66 & \pm & 3.64 & 8.2 & 3.23 & \pm & 2.51 & 7.2 & 1.34 & \pm & 2.20 & 9.7 \\
\hline
\end{tabular}


Table 5: Spearman coefficients of some biological parameters measured during all three cruises and for all the stations together. The "*" symbol corresponds to the level of significance with * for $p<$ $0.05,{ }^{* *}$ for $\mathrm{p}<0.01, * * *$ for $\mathrm{p}<0.001$. No star means that no significant relationship was found between the two parameters tested

\begin{tabular}{lcccc}
\hline & La Pérouse & MAD-Ridge & Walters Shoal & All \\
& $n=10$ & $n=23$ & $n=13$ & $n=46$ \\
\hline Abundance $\sim$ Biovolume & 0.36 & $0.77^{* * *}$ & $0.88^{* * *}$ & $0.84^{* * *}$ \\
Abundance $\sim$ NBSS slope & -0.29 & -0.36 & $-0.64^{*}$ & $-0.61^{* * *}$ \\
Biovolume $\sim$ NBSS intercept & $0.89 * * *$ & $0.91^{* * *}$ & $-0.65^{*}$ & $0.65^{* * *}$ \\
Diversity index $\sim$ NBSS slope & $0.79 *$ & 0.00 & $0.59^{*}$ & $-0.43^{* *}$ \\
Diversity index $\sim$ NBSS linear fit & 0.49 & $0.44^{*}$ & -0.48 & $0.31^{*}$ \\
\hline
\end{tabular}



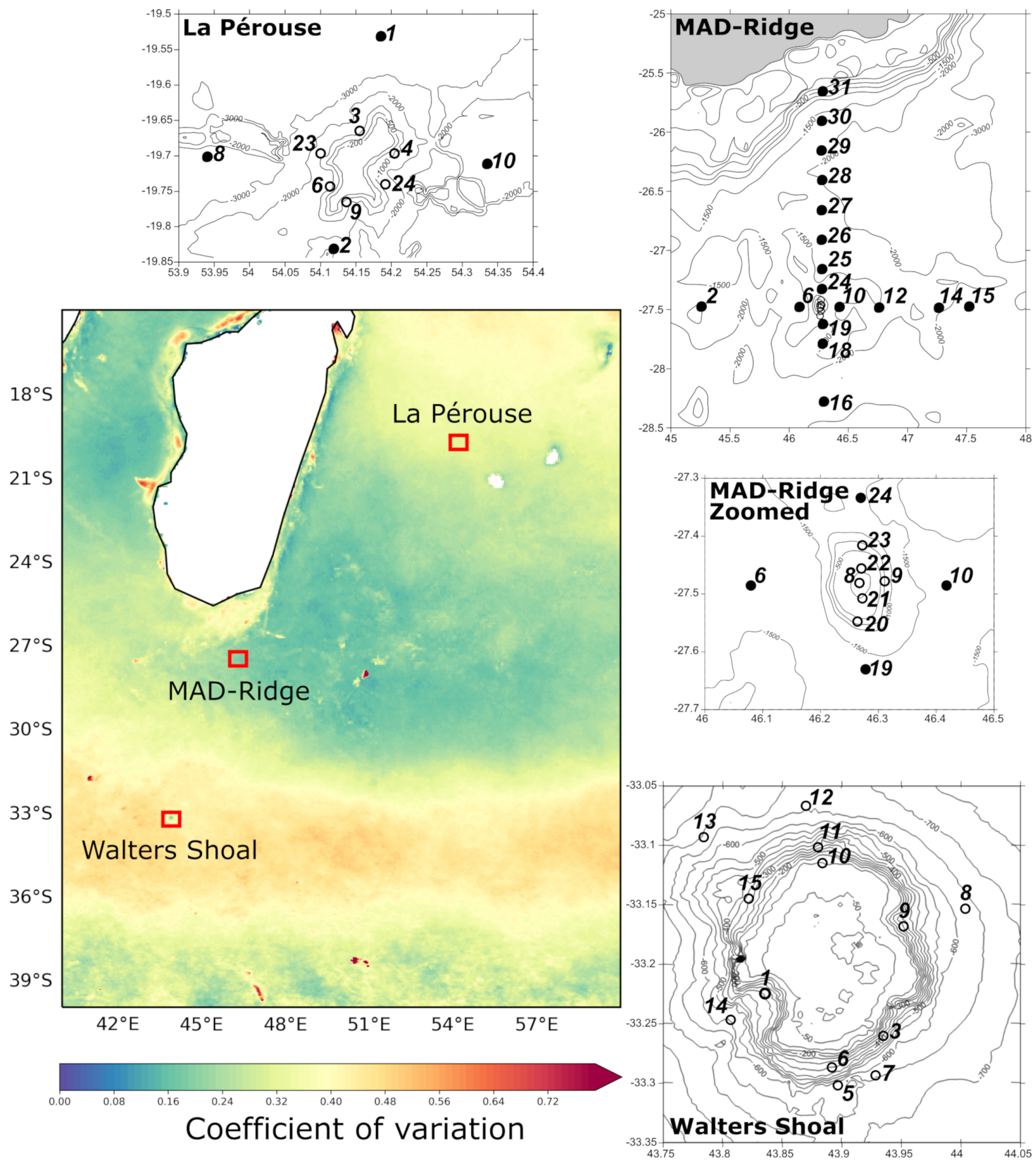


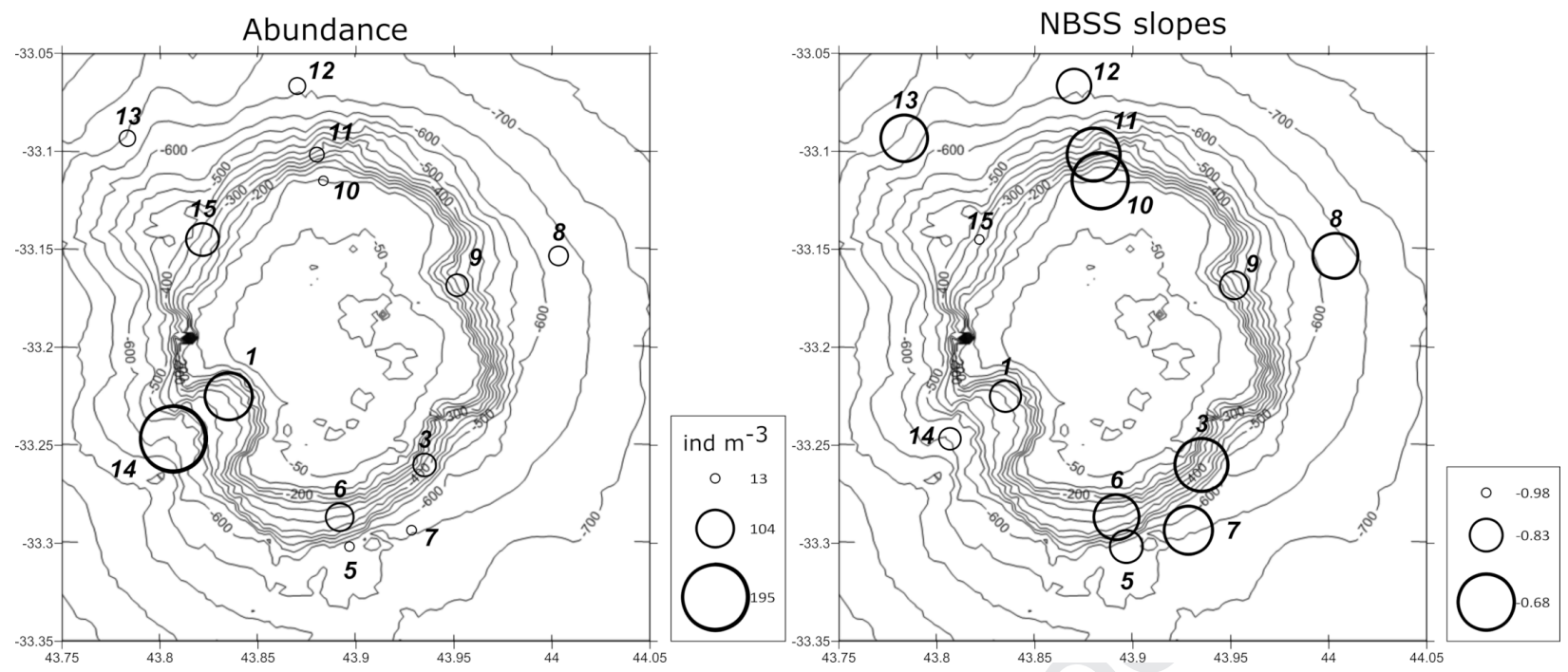




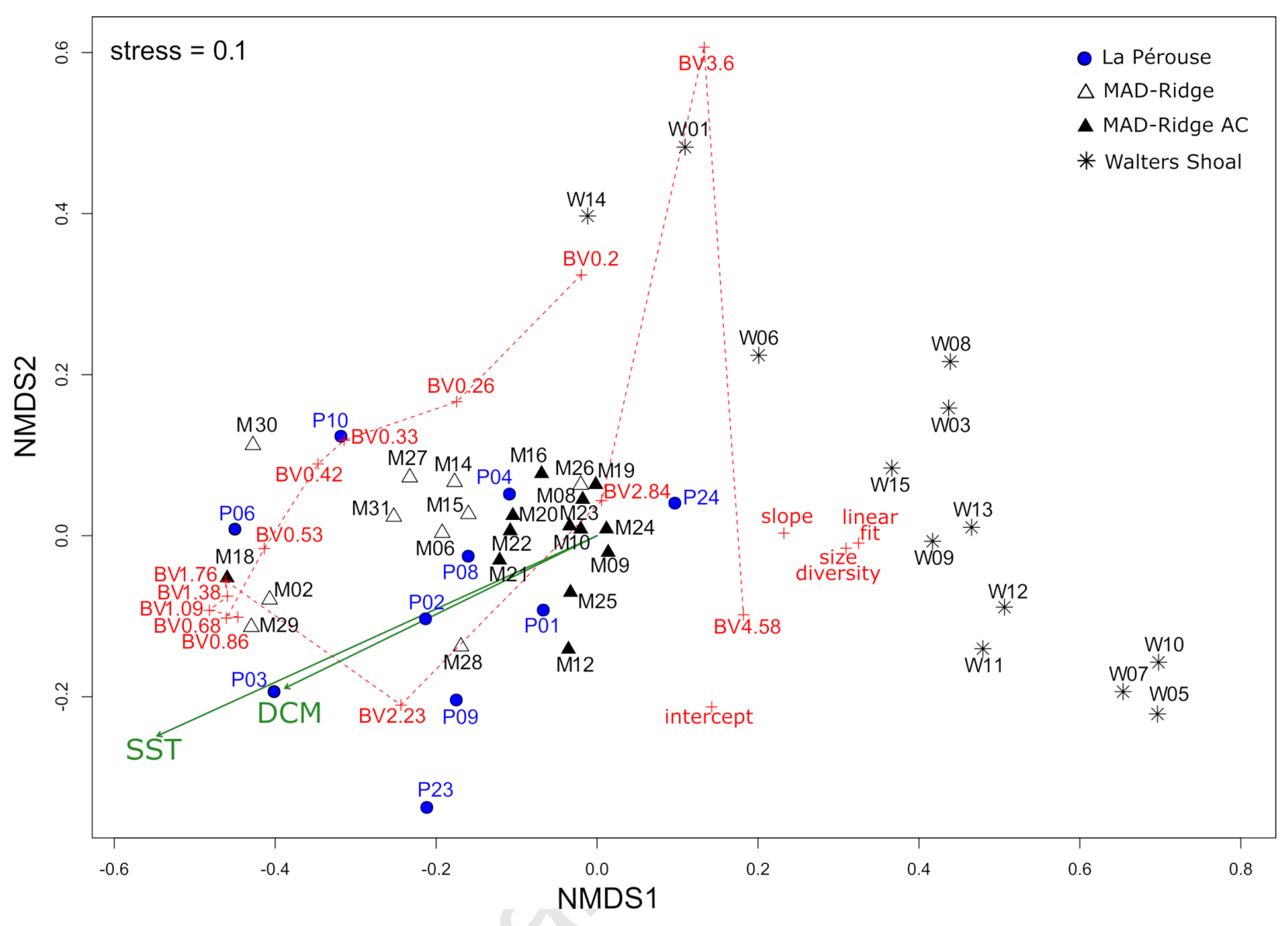




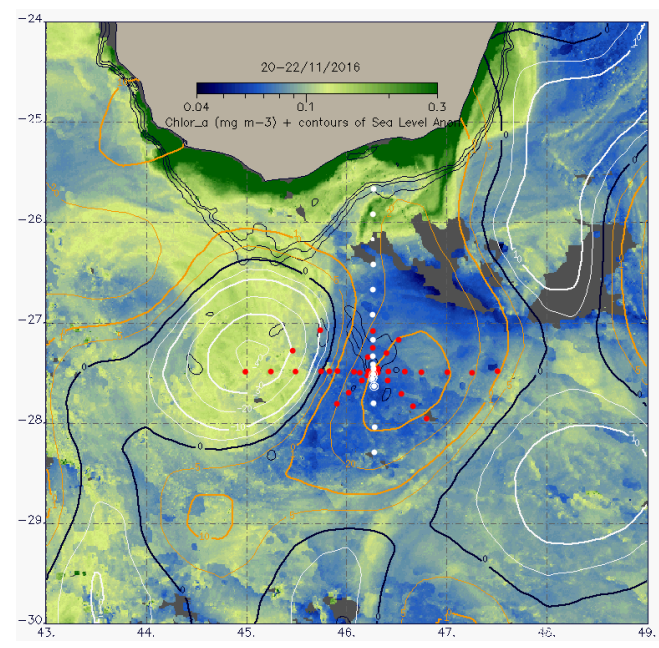



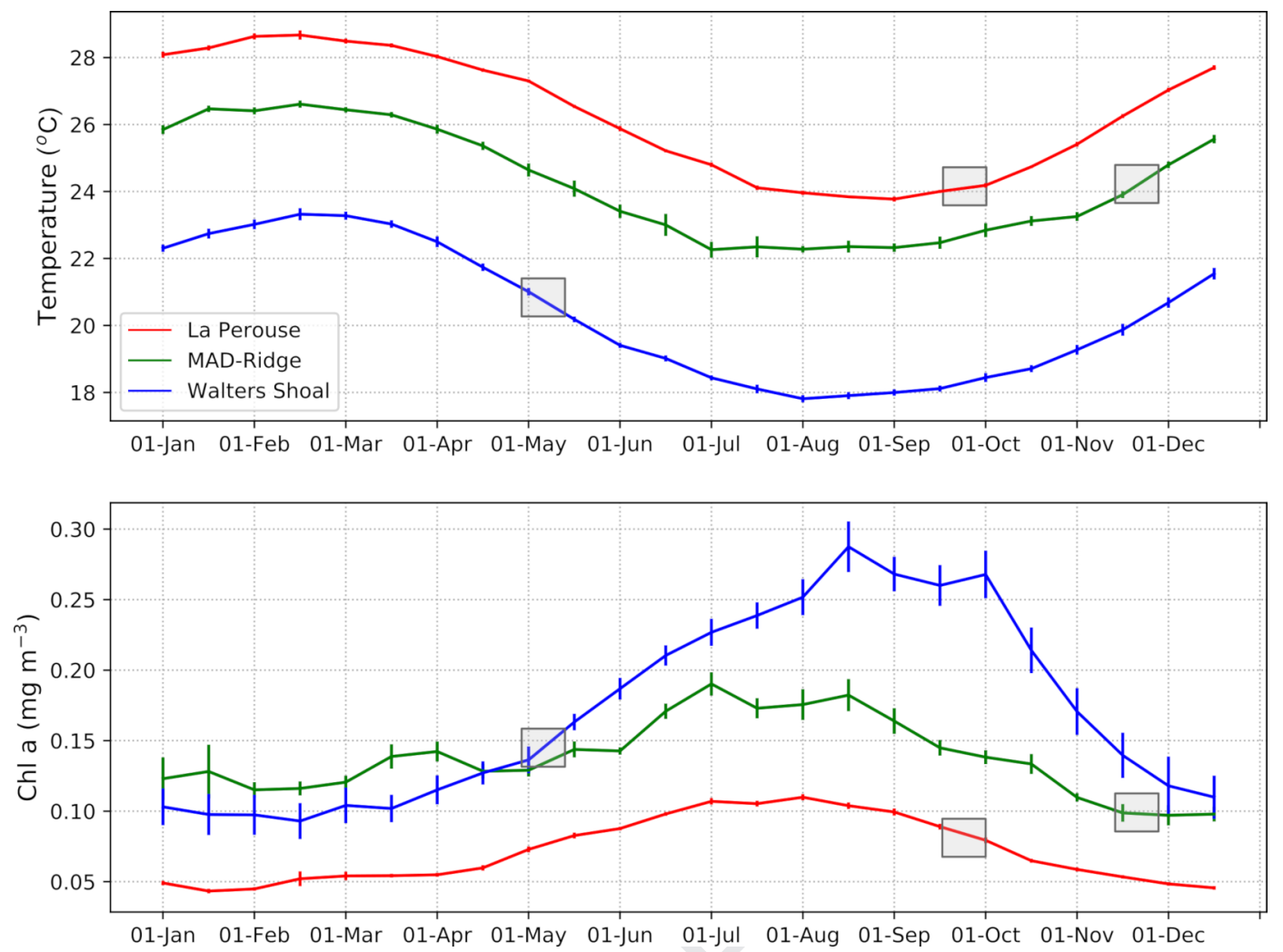


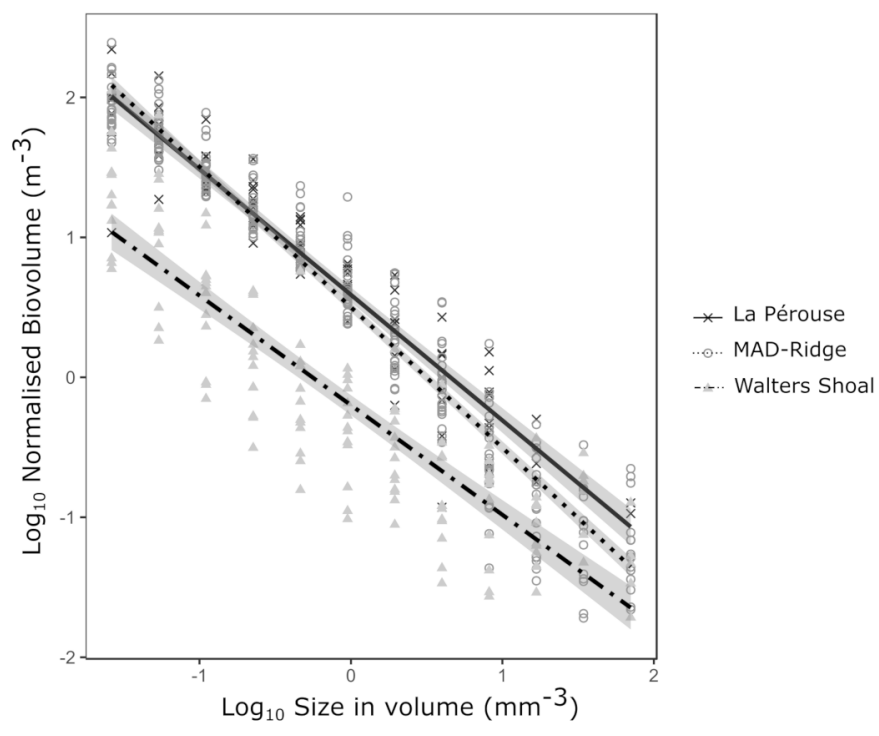



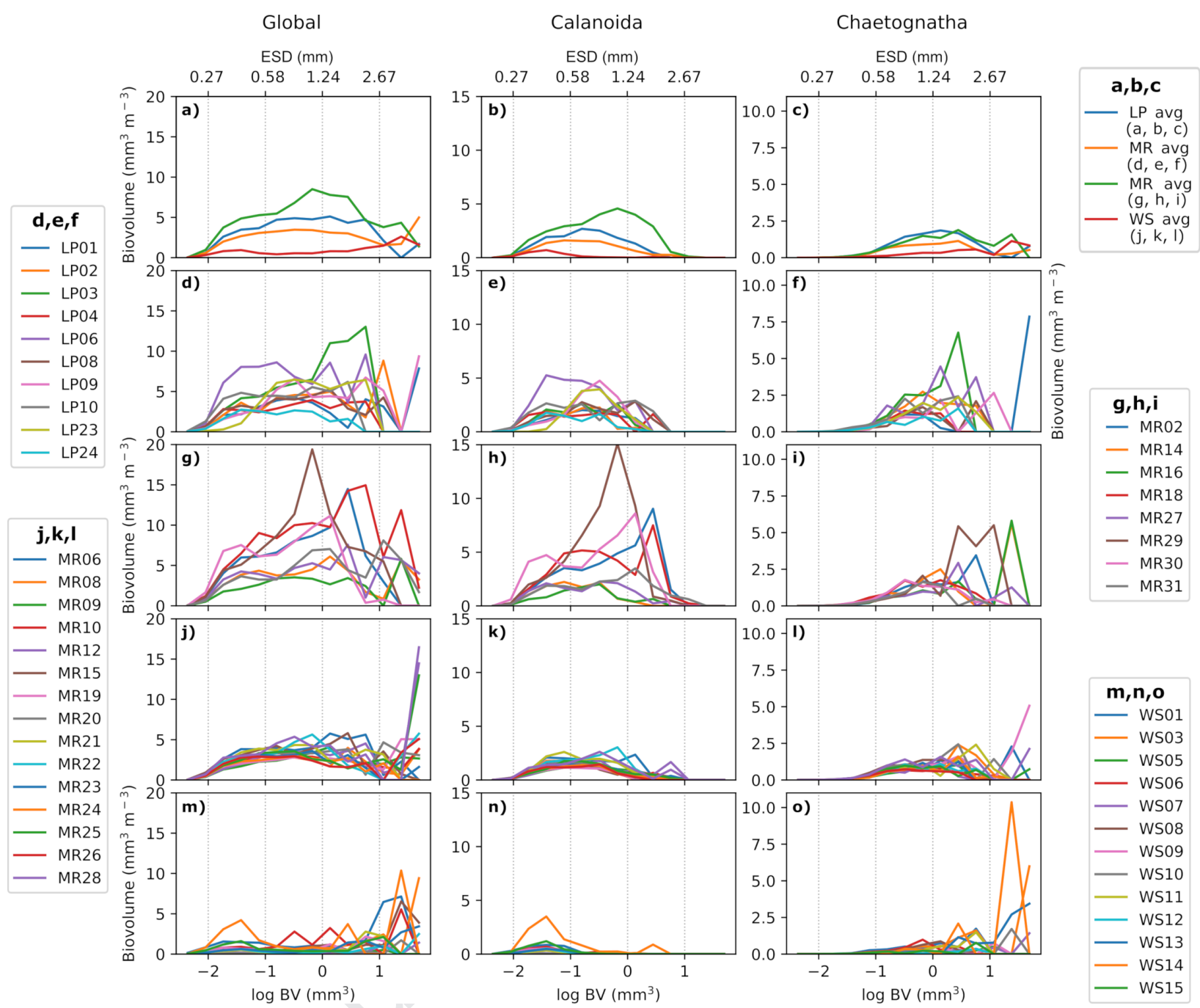


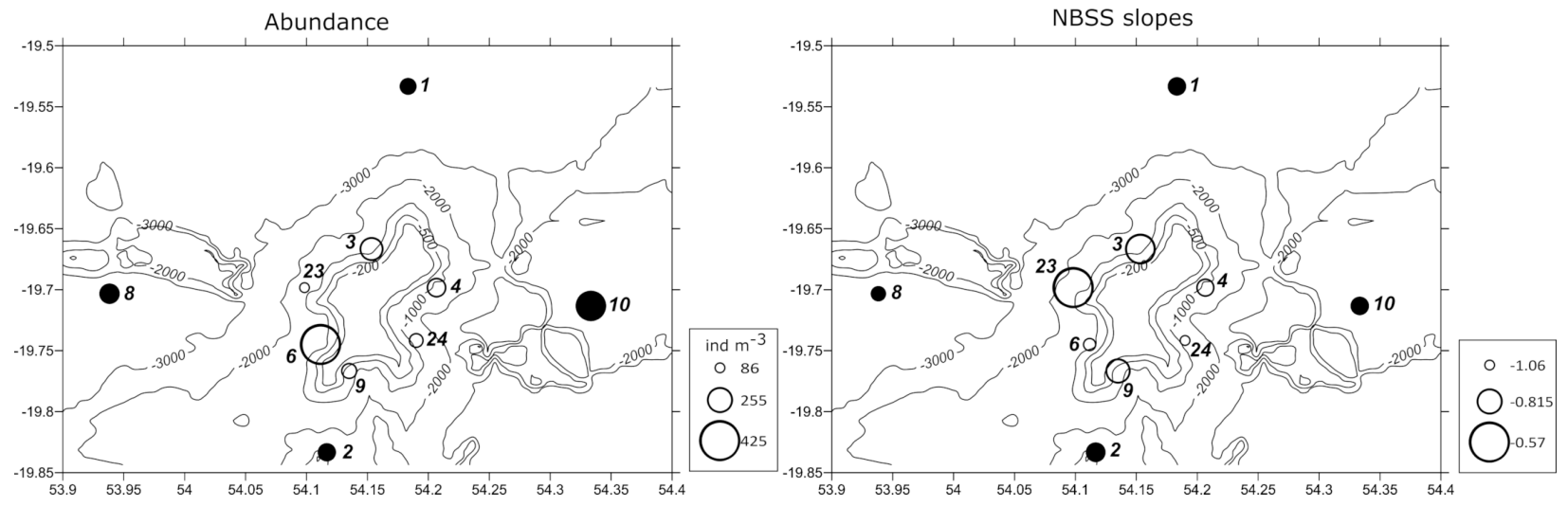




\section{La Pérouse}
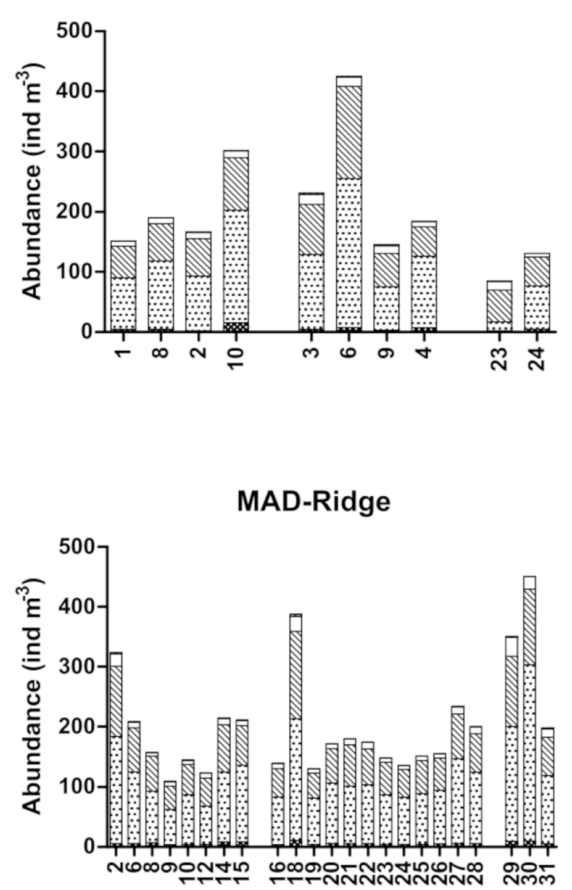

Walters Shoal

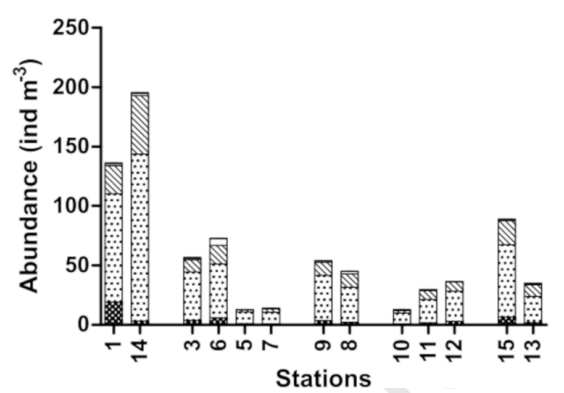

La Pérouse

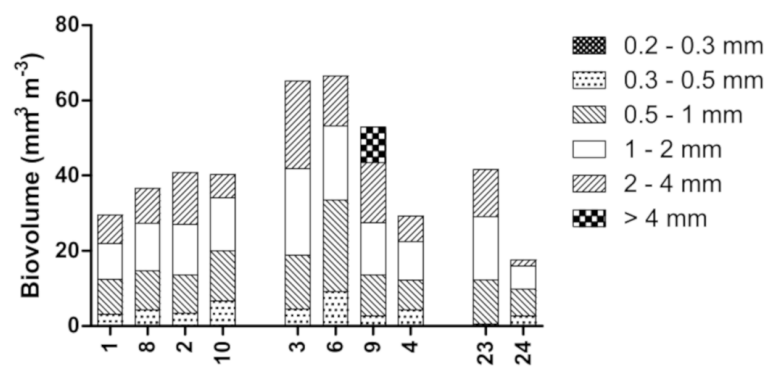

MAD-Ridge

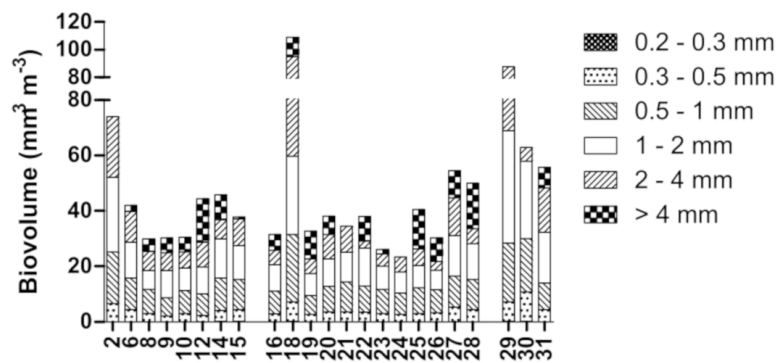

Walters Shoal

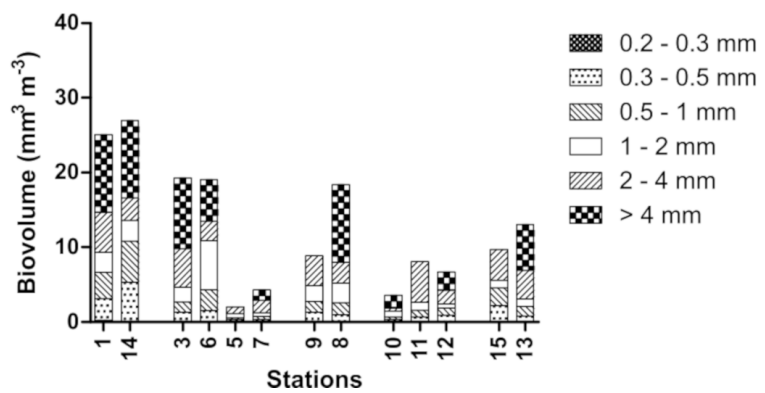



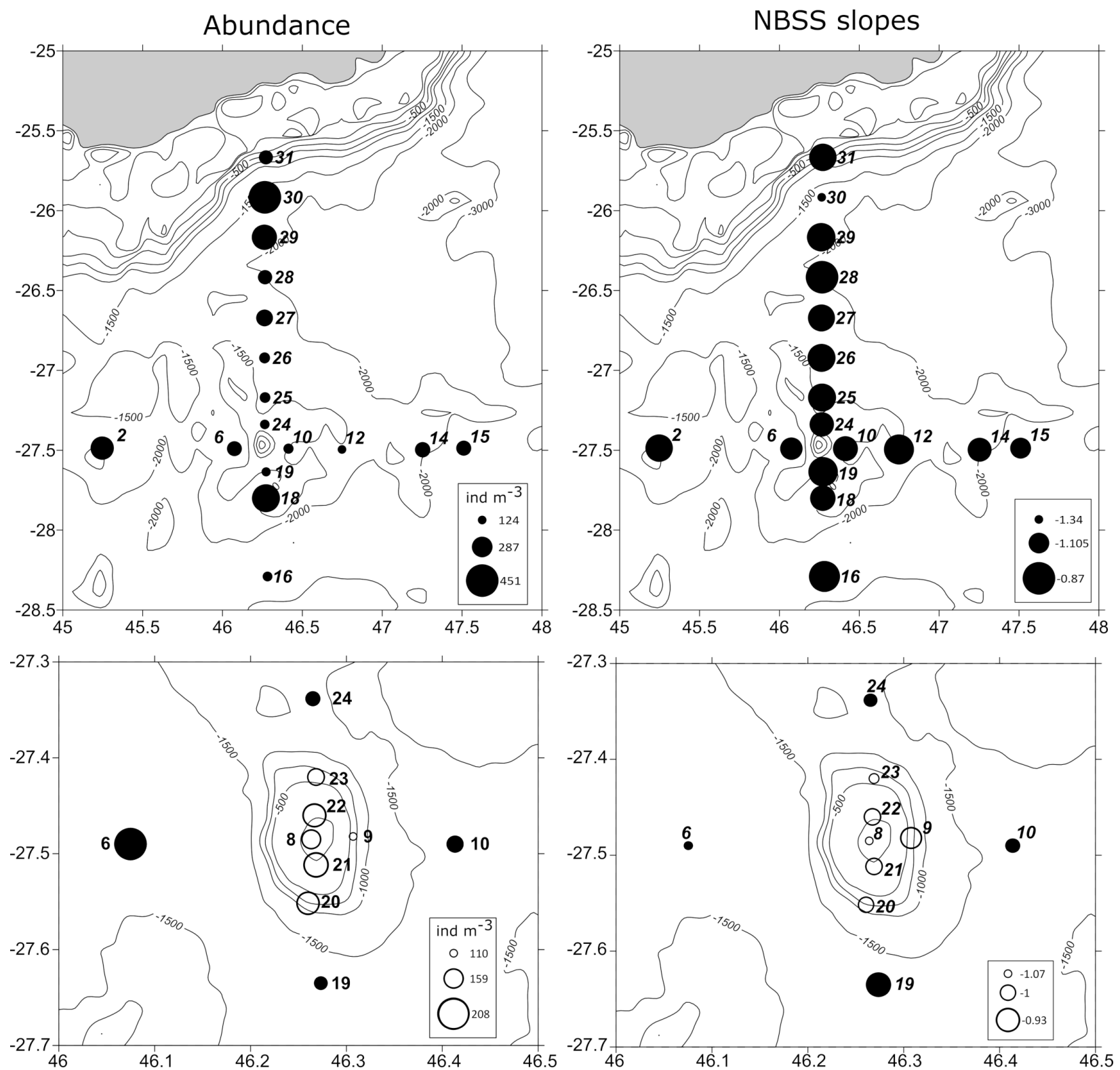

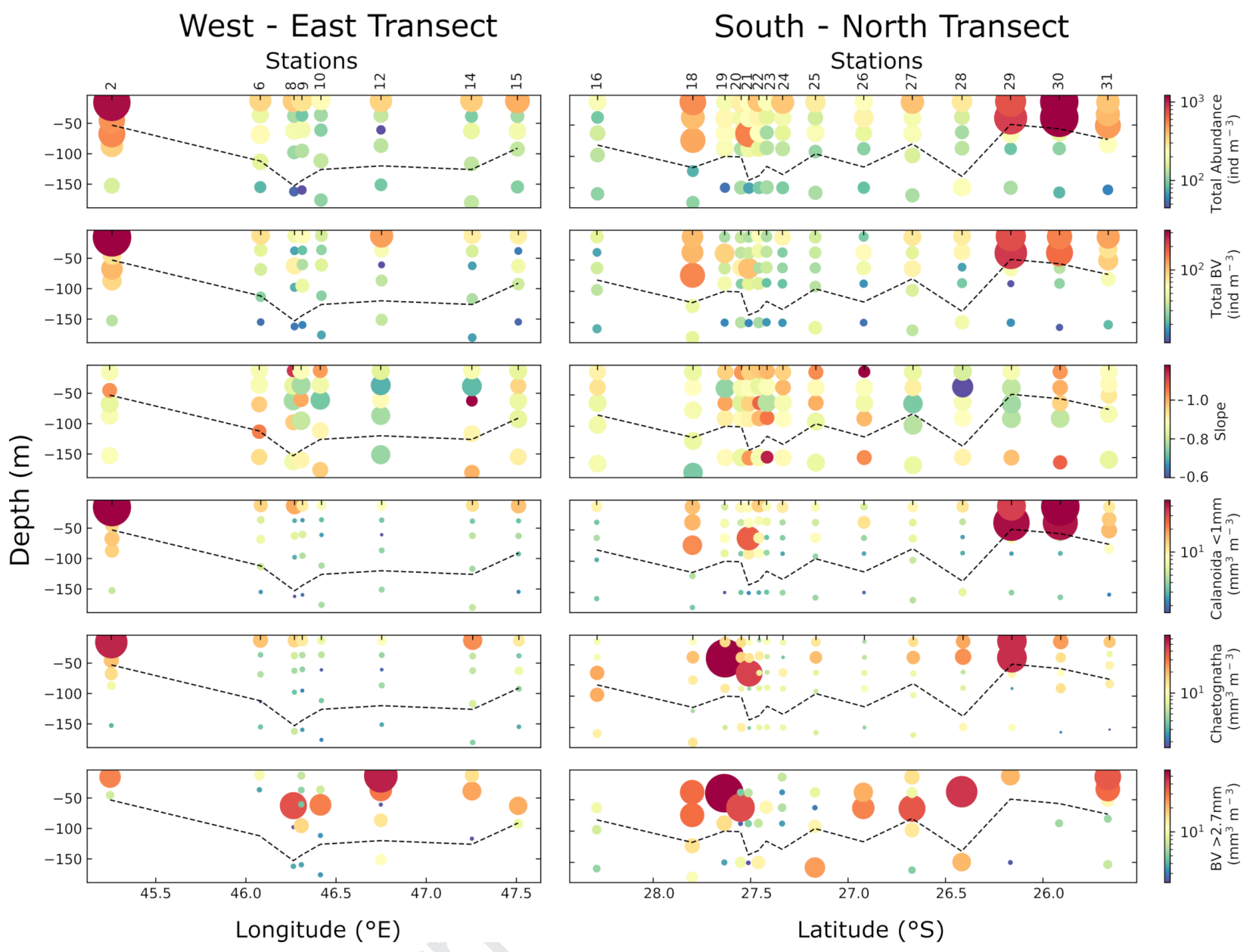